Biogeosciences Discussions is the access reviewed discussion forum of Biogeosciences

\section{A simple parameterization of nitrogen limitation on primary productivity for global vegetation models}

G. Krinner ${ }^{1}$, P. Ciais $^{2}$, N. Viovy ${ }^{2}$, and P. Friedlingstein ${ }^{3}$

${ }^{1}$ Laboratoire de Glaciologie et de Géophysique de l'Environnement, CNRS-UJF Grenoble 1, France

${ }^{3}$ Laboratoire des Sciences du Climat et de l'Environnement, CEA-CNRS Saclay, France

Received: 4 August 2005 - Accepted: 25 August 2005 - Published: 30 August 2005

Correspondence to: G. Krinner (krinner@ujf-grenoble.fr)

(C) 2005 Author(s). This work is licensed under a Creative Commons License.

Print Version

\section{Simple \\ parameterization of nitrogen limitation}

G. Krinner et al.

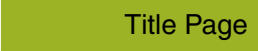

Abstract

Introduction

Conclusions

References

Tables

Figures

14

$>1$

4

Back

Close

Interactive Discussion 


\section{Abstract}

Nitrogen limitation of ecosystem productivity is ubiquitous, and it is thought that it has and will have a significant impact on net ecosystem productivity, and thus carbon sequestration, in the context of ongoing future increase of atmospheric $\mathrm{CO}_{2}$ concentra5 tion and climate change. However, many vegetation models do not represent nitrogen limitation, and might thus overestimate future terrestrial $C$ sequestration. This work presents a simple parameterization of nitrogen limitation that can be easily implemented in vegetation models which do not yet include a complete nitrogen cycle. This parameterization is based on the ratio between heterotrophic respiration (considered a " of net mineralization rate) and net primary productivity of the ecosystem (considered a "proxy" of nitrogen demand). It is implemented in a global vegetation model and tested against site experiments of $\mathrm{CO}_{2}$ fertilization and soil warming. Furthermore, global simulations of past and future $\mathrm{CO}_{2}$ fertilization are carried out and compared to other model results and available estimates of global $C$ sequestration. It is shown that when $\mathrm{N}$ limitation is taken into account using the simple parameterization presented here, the model reproduces fairly realistically the carbon dynamics observed under $\mathrm{CO}_{2}$ fertilization and soil warming.

\section{Introduction}

Our lack of knowledge about the possible positive or negative feedbacks due to modified carbon fluxes of the terrestrial biosphere contribute to the present uncertainties in climate change predictions. Higher atmospheric $\mathrm{CO}_{2}$ concentrations $\left(C_{a}\right)$ will certainly lead to increased carbon sequestration by the terrestrial biosphere. However, Hungate et al. (2003) showed that the vegetation models used in the Third IPCC Assessment Report (IPCC, 2001) are likely to overestimate this carbon accumulation because nutrient - in particular nitrogen - limitation is not taken into account in most state-of-the-art models. This is also shown by model intercomparison studies (e.g. Kicklighter et al.,
BGD

2, 1243-1282, 2005

\section{Simple \\ parameterization of nitrogen limitation}

G. Krinner et al.

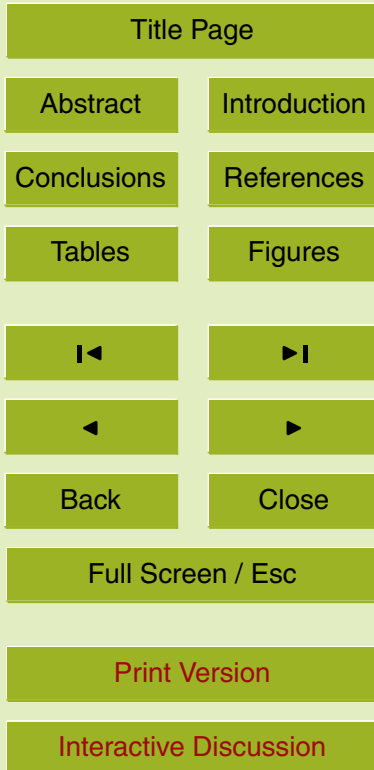

EGU 
1999) which show that the present simulated current terrestrial carbon sink caused by $\mathrm{CO}_{2}$ fertilization is clearly lower when nitrogen limitation is taken into account.

Nitrogen limitation is ubiquitous in terrestrial ecosystems (Vitousek and Howarth, 1991), but it is particularly strong in boreal and arctic regions (Hobbie et al., 2002) 5 because cold and often wet conditions act to slow the release of mineral $\mathrm{N}$ from organic matter and to impede the oxidation of organic $\mathrm{C}$ to $\mathrm{CO}_{2}$. However, a model-based study by Schimel et al. (1997) indicates that in steady state conditions, water/energy and nitrogen limitation will tend to "equilibrate", because carbon, water, and nitrogen fluxes are strongly correlated. Therefore, taking nitrogen limitation into account in model 10 studies of equilibrium states might not be absolutely necessary, except in permafrost regions where such an equilibrium cannot be obtained because soil organic matter "disappears" from the active biosphere (through incorporation of this matter into the permafrost below the active layer) before decomposition and mineralization can occur. On the other hand, Schimel et al. (1997) note that, because carbon, water, and nitrogen 15 cycles have different response times to perturbations, studies of transient climate or environmental change require that the interactions between these cycles be taken into account. The concept of "progressive nitrogen limitation" (Luo et al., 2004) constitutes a framework for the understanding of these transient effects in the case of present-day $C_{a}$ increase and climate change. Progressive nitrogen limitation describes the tendency of available soil $\mathrm{N}$ to become increasingly limiting as $\mathrm{C}$ and $\mathrm{N}$ are sequestered in longlived plant biomass and soil organic matter. Implicitly, it supposes a quasi-closed $\mathrm{N}$ cycle in which nitrogen fluxes within the ecosystem are much more important than external sources or losses; this view seems justified (Schimel et al., 1997; Nadelhoffer et al., 1999), particularly in the context of adjustment to rapid climate change or $C_{a}$ 25 increase.

A long-term $\mathrm{CO}_{2}$ fertilization experiment in a northern mid-latitude forest $\left(\mathrm{FACE}_{\mathrm{P}}\right.$, Oren et al., 2001) showed nitrogen limitation of annual $C$ increment in woody tissue after a few years of initially increased productivity (DeLucia et al., 2004). This limitation was caused by the gradual depletion of soil $\mathrm{N}$ due to the increased demand. $\mathrm{A}$
BGD

2, 1243-1282, 2005

\section{Simple parameterization of nitrogen limitation}

G. Krinner et al.

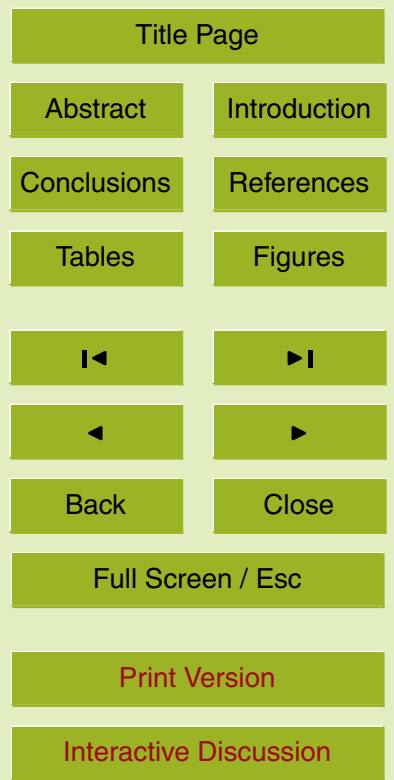

EGU 
similar effect had been reported before by Oechel et al. (1994) for $\mathrm{CO}_{2}$ fertilization experiments in the Arctic tundra. In these experiments, the net ecosystem $\mathrm{CO}_{2}$ fertilization effect, initially positive, vanished in the third year of the treatment. When, in addition to $C_{a}$, temperature was artificially increased by $4^{\circ} \mathrm{C}$, the net ecosystem $\mathrm{CO}_{2}$ 5 fertilization effect remained positive in the third year of the treatment, probably because of increased nutrient availability in the soil due to increased microbial activity. This is coherent with the results of a soil warming experiment in the Harvard mixed temperate forest (Melillo et al., 2002), which showed increased nitrogen availability, and therefore more vigorous plant growth, as a consequence of the stimulated microbial activity. 10 Melillo et al. (2002) concluded that the more vigorous plant growth had the potential to offset the increased soil microbial respiration. However, such an effect can be transient in turn. In a long-term $\mathrm{CO}_{2}$ fertilization experiment in a grassland, $\mathrm{Hu}$ et al. (2001) reported reduced microbial decomposition, due to nitrogen limitation, after a few years of increased microbial activity and accelerated C cycling (Hungate et al., 1997). For 15 cases of particularly strong nutrient limitation, total absence of any $\mathrm{CO}_{2}$ fertilization effect has been reported reported. For example, Hoosbeek et al. (2001) report that a $\mathrm{CO}_{2}$ fertilization experiment on ombotrophic bog vegetation in Finland, using FACE technology, yielded only insignificant plant biomass increase. On the other hand, some $\mathrm{CO}_{2}$ fertilization experiments, such as the FACE experiment in a sweetgum plantation on Oak Ridge National Environmental Research Park in Tennessee, USA (Norby et al., 2002), did not show any signs on progressive nitrogen limitation during the course of the experiment, with the $\mathrm{CO}_{2}$ fertilization effect remaining more or less constant.

One of the main reasons why many vegetation models in use today do not represent the nitrogen cycle is that the interactions between the carbon and nitrogen cycle are extremely complicated and far from perfectly understood. For example, it has long been thought that, in boreal ecosystems, warming would accelerate decomposition of plant litter and therefore lead to increased nutrient availability, which, in turn, would stimulate plant production and increase ecosystem carbon storage (Hobbie et al., 2002). But Mack et al. (2004) recently reported results of a long-term fertilization experiment in
BGD

2, 1243-1282, 2005

\section{Simple parameterization of nitrogen limitation}

G. Krinner et al.

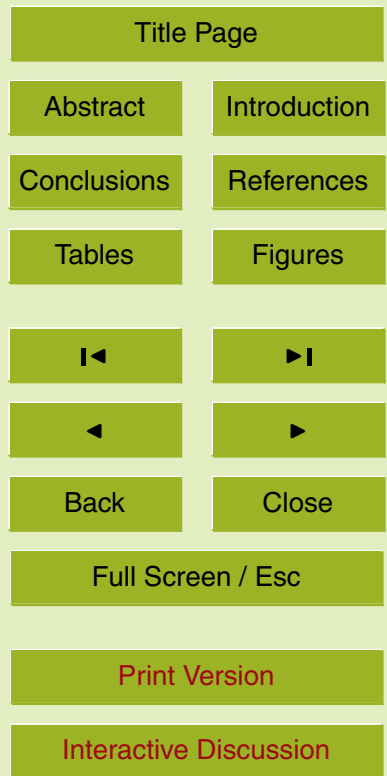

EGU 
Alaskan tundra which indicate that increased nutrient availability in arctic soils leads to reduced ecosystem carbon storage because soil bacterial activity is currently also strongly nitrogen limited. More generally, the effect of nitrogen fertilization on stability and turnover of soil carbon is rather complicated because of varying impacts of $\mathrm{N}$ 5 addition on the different soil carbon reservoirs (Neff et al., 2002). Our understanding of coupled ecosystem $\mathrm{C} / \mathrm{N}$ dynamics is further hampered by the fact that results of short-term experiments can often be misleading, and that other elements may play an important role. For example, a recent study by Hungate et al. (2004) shows that the previously reported increase of biological $\mathrm{N}$ fixation with rising $C_{a}$ (Poorter, 1993), 10 which was thought to provide the $\mathrm{N}$ necessary to support increased $\mathrm{C}$ accumulation induced by rising $C_{a}$, is in fact only transient: after 5 years of growth under elevated $C_{a}$, a consistent decrease of legume $\mathrm{N}$ fixation, probably due to the onset of molybdenum limitation, was observed.

Here we present a simple parameterization of nitrogen limitation on primary produc15 tivity included in a dynamic global vegetation model called ORCHIDEE (Krinner et al., 2005). This parameterization was designed to represent, as discussed above, progressive nitrogen limitation (Luo et al., 2004) after climate change or a change in $C_{a}$, and the particularly strong "equilibrium" nitrogen limitation in cold regions subject to permafrost. However, the general case of "equilibrium" $\mathrm{N}$ limitation is not represented by the scheme because, as stated before, Schimel et al. (1997) indicate that in steady state conditions, water/energy and nitrogen limitation will tend to "equilibrate" because carbon, water, and nitrogen fluxes are strongly correlated. The motivation for taking into account the particularly strong "equilibrium" nitrogen limitation in cold regions subject to permafrost was that ORCHIDEE overestimates forest net primary productivity 25 (NPP) in Eastern Siberia, while it correctly simulates the observed productivity in Europe: Krinner et al. (2005) speculated that this misfit might be due to the fact that the standard version of the model does not take into account the regionally varying nitrogen limitation. This simple parameterization is to be seen as a tool designed to allow to take into account particularily important cases of $\mathrm{N}$ limitation in models which do not

BGD

2, 1243-1282, 2005

\section{Simple parameterization of nitrogen limitation}

G. Krinner et al.

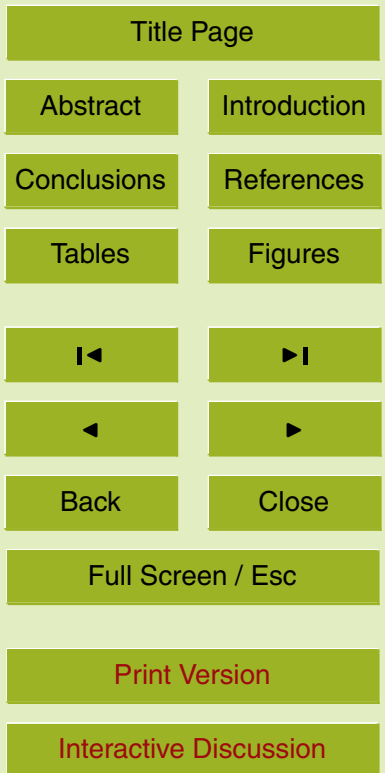

EGU 
include a complete prognostic nitrogen cycle. The final goal should be to include the $\mathrm{N}$ cycle in biosphere models, but as long as this is not the state of the art, the simple scheme presented here could be helpful. The following section describes this parameterization. Results from numerical $\mathrm{CO}_{2}$-fertilization experiments, both on global and 5 local scales, are presented thereafter, followed by a discussion of the parameterization and the model results.

\section{Parameterization}

\subsection{Description}

In its baseline version (Krinner et al., 2005), ORCHIDEE calculates prognostic vegetation 10 and soil carbon stocks. Heterotrophic respiration from three soil carbon pools (active, slow, and passive) and four litter pools (structural and metabolic litter, above and below ground) is parameterized following Parton et al. (1988). C: $N$ ratios of plant tissues are prescribed and determine the litter quality. Nitrogen limitation on primary productivity is not taken into account.

15 In the modified version of ORCHIDEE, $\mathrm{N}$ limitation on primary productivity is taken into account by modifying the maximum potential photosynthetic capacity (that is, unstressed photosynthetic capacity at optimum temperature) $V_{\max , 0}$ :

$V_{\max }=V_{\max , 0} a_{N}$.

Here, $V_{\max 0}$ depends on the leaf age and on the PFT, as described by Krinner et al. 20 (2005). The nitrogen availability $a_{N}$ is parameterized as depending on the ratio between long-term heterotrophic respiration $R_{H}$ and long-term NPP $P_{N}$ :

$a_{N}=\frac{R_{H}}{P_{N}}$.

Here, the "long-term" variables are calculated through linear relaxation with a time constant of $\tau=7 \mathrm{y}$ for NPP and $\tau=3 \mathrm{y}$ for heterotrophic respiration. The rationale for this

\section{Simple \\ parameterization of nitrogen limitation}

G. Krinner et al.

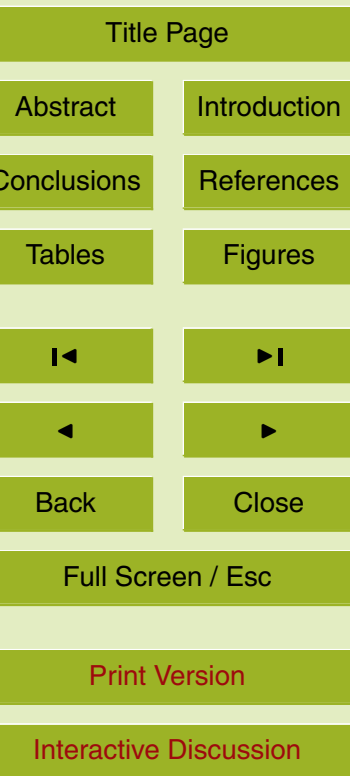

EGU 
parameterization of $a_{N}$ is as follows. Nitrogen limitation will depend on the balance between demand and supply. The main supply of $\mathrm{N}$ in unperturbed natural soil is generally mineralization through bacterial activity (Vitousek and Howarth, 1991). Nitrogen demand is, for obvious reasons, tightly linked to plant productivity. By definition, if the 5 ecosystem is in equilibrium, net ecosystem productivity will be zero, that is $P_{N}=R_{H}$, and therefore $a_{N}=1$. If NPP increases strongly, for example after a sudden increase of $C_{a}$, nitrogen availability will decrease after a few years because $R_{H}$, representing $\mathrm{N}$ supply, will not increase quickly. This gradual depletion of the nitrogen reservoir, seen in many $\mathrm{CO}_{2}$ fertilization experiments (e.g. Oechel et al., 1994; Oren et al., 2001), then leads to 10 a strong reduction of the $\mathrm{CO}_{2}$ fertilization effect after several years of initially increased primary productivity. On the other hand, in soil warming experiments (Melillo et al., 2002; Oechel et al., 1994), inceased nitrogen availability seems to occur fairly rapidly, faster than gradual nitrogen depletion in $C_{a}$ fertilization experiments. Based on these observations, the linear relaxation constant $\tau$ was set to 7 years for "long-term" NPP, and 3 years for heterotrophic respiration.

Strong $\mathrm{N}$ limitation in boreal regions occurs because soil bacterial activity is weak due to the low temperatures. This is particularly true in regions subject to permafrost, where soil organic matter can be locked below the permafrost horizon before being decomposed. Enormous quantities of organic carbon, thought to represent about one third to one quarter of the total global soil carbon (Stokstad, 2004), have therefore accumulated in permafrost soils. To represent this effect, the original parameterization of heterotrophic respiration has been modified to take into account the regular "export" of soil carbon from the active layer, where decomposition can occur, towards the permafrost. The soil respiration scheme in ORCHIDEE has no vertical discretization, and the whole soil carbon is decomposed using parameterizations of bacterial activity dependent on temperature and humidity at typical decomposer depth of about 20 $\mathrm{cm}$. In reality, soil matter deeper in the ground will decompose very slowly because of decreasing oxygen availability. To represent the effect of accumulation of organic matter and the subsequent gradual export of matter from the active layer towards the

BGD

2, 1243-1282, 2005

\section{Simple parameterization of nitrogen limitation}

G. Krinner et al.

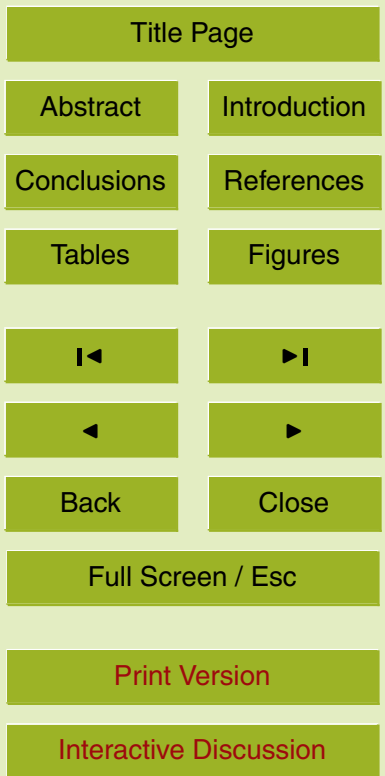

EGU 
permafrost, the modified scheme translates the total accumulated soil carbon into an equivalent minimum depth of this organic layer, supposing a maximum soil carbon density of $\rho_{c, m}=30 \mathrm{kgC} / \mathrm{m}^{3}$ of soil matter. As significant heterotrophic respiration will only occur in the first meter of soil or so, one can suppose an exponential distribution of 5 maximum decomposable carbon $C_{d, m}$ such that

$\rho_{c}=\rho_{c, m} \exp \left(-z / z_{0}\right)$,

with $z_{0}=1 \mathrm{~m}$. Total maximum decomposable soil carbon $C_{d, m}$ between 0 and infinite depth is then

$C_{d, m}=\int_{0}^{\infty} \rho_{c} d z=30 \mathrm{kgC} / \mathrm{m}^{2}$.

10 Such quantities of soil carbon are usually only reached in boreal regions (Batjes, 2000). At any given moment of the year, the depth of the freeze and thaw fronts $\left(d_{f}\right.$ and $d_{t}$, respectively) in the ground can be calculated using the diagnostic Stefan equations:

$d_{t}=\sqrt{\frac{2 \lambda}{L} \int_{t_{0}}^{t} \Delta T_{t} d t}$

with $\Delta T_{t}=\max \left(T-0^{\circ} \mathrm{C}, 0\right)$, and

15

$d_{f}=\sqrt{\frac{2 \lambda}{L} \int_{t_{0}}^{t} \Delta T_{f} d t}$

with $\Delta T_{f}=\max \left(0^{\circ} \mathrm{C}-T, 0\right)$. Here, $\lambda$ is the soil heat conductivity and $L$ is the volumetric latent heat released or taken up during phase transitions, $T$ is the surface temperature, and $t_{0}$ is midwinter in Eq. (5) and midsummer in Eq. (6). Using these equations, and supposing that almost no decomposition occurs in soil at sub-zero temperatures (Zimov et al., 1996), one can easily determine, at each time step, how much carbon $C_{d}$ can at best be accessible to decomposer activity. Calculated heterotrophic decomposition
BGD

2, 1243-1282, 2005

\section{Simple parameterization of nitrogen limitation}

G. Krinner et al.

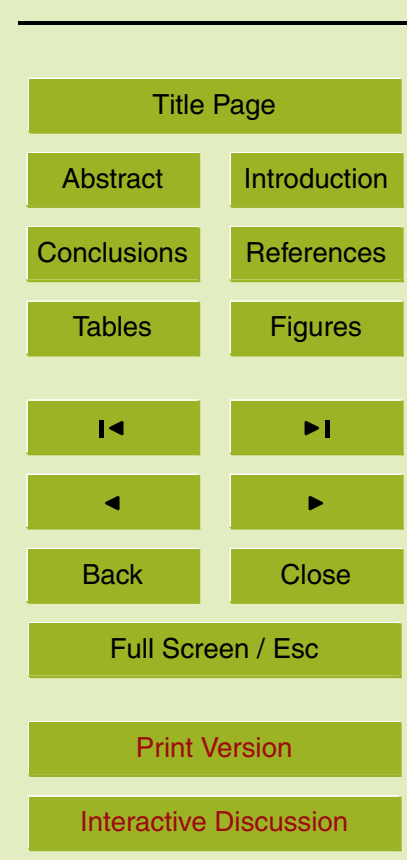

EGU 
will then be limited to this quantity $C_{d}$, even if total soil carbon $C>C_{d}$. In this way, heterotrophic respiration will be limited to the active layer where permafrost is present, and inactive carbon will accumulate. This should lead to increased $\mathrm{N}$ limitation, as typically observed.

5 The underlying assumptions and the limitations of this parameterization are discussed in Sect. 5 together with the model results.

\section{Simulations}

For all simulations, the model was forced at its half-hourly time step by meteorological parameters obtained from a Richardson-type weather generator (Foley, personal 10 communication; Richardson and Wright (1984); Friend (1998)). All simulations were carried out with prescribed $C_{a}$ from 1800 to present (Etheridge et al., 1998; Keeling and Whorf, 2004). Note that the weather generator does produce artificial interannual climate variability. Extreme climate events (droughts, heat waves, cold shocks, etc.) and their impacts on vegetation are therefore represented in the simulations.

15 The scheme was evaluated using simulations reproducing the $\mathrm{FACE}_{\mathrm{p}} C_{a}$ enrichment experiment at Duke Forest (Oren et al., 2001), the FACE $C_{a}$ enrichment experiment at Oak Ridge (Norby et al., 2002), and the Harvard soil warming experiment (Melillo et al., 2002).

Furthermore, global simulations from 1800 to 2100 were carried out to analyze the response to a gradual increase in $C_{a}$, with and without $\mathrm{N}$ limitation. Particular specifications for each of these simulations will be described in the following.

\section{1. $\mathrm{FACE}_{\mathrm{P}} \mathrm{CO}_{2}$ enrichment experiment at Duke Forest}

The history of the $F A C E_{P}$ site before the 20th century is rather uncertain. It is possible, but not sure, that the site was grass-covered during the late 1700s and early 1800s.

It was covered by a mixed hardwood forest in the 1920s. This forest was clear-cut

BGD

2, 1243-1282, 2005

\section{Simple \\ parameterization of nitrogen limitation}

G. Krinner et al.

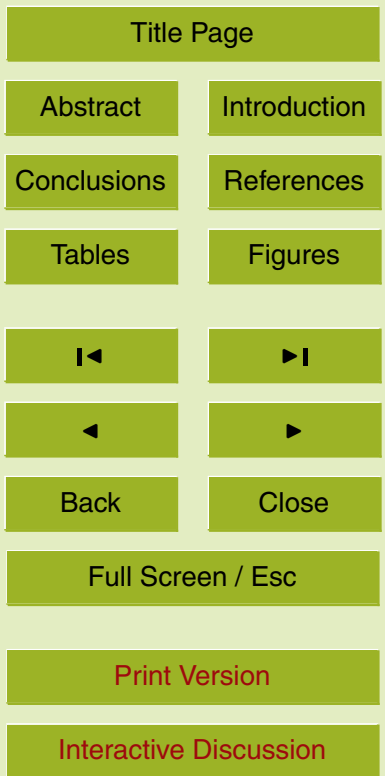

EGU 
and replaced by a loblolly pine plantation in 1983. Similar to the simulations for the Harvard forest site, the model was initialized at the year $0 \mathrm{BC}$ with present-day natural vegetation, that is, temperate mixed forest. It was then run for 1800 years with dynamic vegetation and fixed $C_{a}(280 \mathrm{ppm})$. We used monthly climatological data for 5 1961-1990 produced by New et al. (1999) as input for the weather generator. In order to accelerate convergence towards soil carbon equilibrium, the soil carbon scheme was run separately for 1000 years every 100 years during the first 8 centuries of the simulation, using mean litter input, soil temperature and soil humidity from the preceding 100 years of the full model simulation (this is similar to the procedure described in

10 Krinner et al. (2005)). From 1800 to 1992, historic $C_{a}$ was used to force the model, but due to the uncertainties about the site history, no vegetation change was prescribed in the model. The loblolly pine plantation (beginning in 1983) was represented by a prescribed $98 \%$ areal coverage with the corresponding model PFT (temperate needleleaf evergreen trees) and low initial biomass (corresponding to newly established saplings) 15 in 1983. Above-ground biomass of the clear-cut forest was supposed to have been removed, while below-ground biomass was assigned to below-ground litter. The initialization procedure was gone through both with the original model and with the model version including the nitrogen limitation parameterizations, and two simulations for 10 model years were carried out for each of the model versions: one control simulation with ambient observed $C_{a}$, and one with $C_{a}$ increased by $200 \mathrm{ppm}$ with respect to the control simulation.

\subsection{FACE $\mathrm{CO}_{2}$ enrichment experiment at Oak Ridge}

In fall, 1988, a sweetgum plantation was established on an old terrace of the Clinch River. The canopy is closed. The model was initialized in the same way as for the $25 \mathrm{FACE}_{\mathrm{P}} \mathrm{CO}_{2}$ enrichment experiment at Duke Forest. In model year 1988, the obtained natural vegetation (temperate mixed forest) was replaced by full coverage with young temperature broadleaf evergreen trees, which is the PFT corresponding to sweetgum (Liquidambar styraciflua). Concerning above and below ground biomass and soil car-

\section{Simple parameterization of nitrogen limitation}

G. Krinner et al.

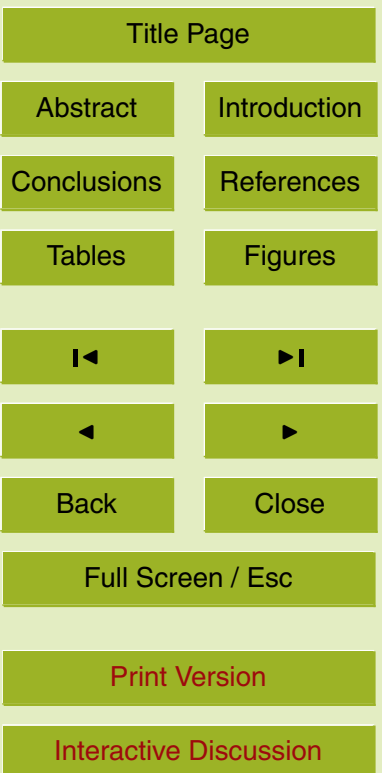

1252 
bon in the model, the transition from natural vegetation to sweetgum plantation was handled as for the $\mathrm{FACE}_{\mathrm{P}} \mathrm{CO}_{2}$ enrichment experiment at Duke Forest. The three-year FACE experiment began in 1997 with an average $C_{a}$ offset of $+180 \mathrm{ppm}$ in the enriched plots. Again, we used monthly climatological data for 1961-1990 produced by 5 New et al. (1999) as input for the weather generator.

\subsection{Harvard soil warming experiment}

The Harvard soil warming experiment was carried out in an even-aged mixed hardwood forest which established after the abandonment of agricultural cultivation of the site around 1900 . Soil temperature was increased by $5^{\circ} \mathrm{C}$ in heated plots and left unchanged in control plots. The model was initialized at the year $0 \mathrm{BC}$ with presentday vegetation. It was then run for 1800 years with dynamic vegetation and fixed $C_{a}$ (280 ppm). Model soil carbon equilibrium was attained in the same way as for the FACE $_{\mathrm{P}}$ simulations. In model year 1800 , the modeled forest was replaced by $\mathrm{C}_{3}$ agriculture. Soil litter was reinitialized at this stage, while soil carbon is taken from the end of the $1800(+8 \times 1000)$ years of carbon spinup. After 90 model years (i.e. in model year 1890), dynamic vegetation was switched on again, resulting in a mixed hardwood forest in model year 1990. Again, at the transition from agriculture to the new forest, soil carbon was not re-initialized, while this was done for biomass and other vegetationrelated variables. The initialization procedure was gone through both with the original 20 model and with the model version including the nitrogen limitation parameterizations. Starting from the soil carbon, soil litter, and vegetation status obtained for model year 1991, two simulations (10 years each) were carried out for each of the model versions: one in which heterotrophic respiration in the soil was subject to increased soil temperature $\left(+5^{\circ} \mathrm{C}\right)$ and one with unmodified soil temperature. As for the other single-point 25 simulations, monthly climatological data for 1961-1990 produced by New et al. (1999) were used.
BGD

2, 1243-1282, 2005

\section{Simple parameterization of nitrogen limitation}

G. Krinner et al.

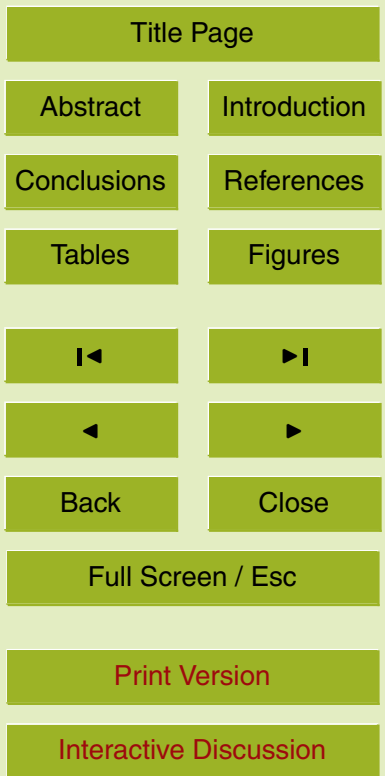

EGU 
With both model versions, global simulations were run at $4^{\circ} \times 2.5^{\circ}$ (zonal $\times$ meridional) resolution as in Krinner et al. (2005). We used monthly climatological data for 19611990 produced by New et al. (1999) and added simulated decadal climate anomalies

5 from transient climate change simulations with the IPSL climate model (historical and, for the present to 2100, a SRESA1B scenario run). The model was run to equilibrium with prescribed present-day vegetation (Loveland et al., 2000) (including present agriculture), $C_{a}=284 \mathrm{ppm}$ and preindustrial climate for the early $1800 \mathrm{~s}$. Afterwards, transient simulations from 1800 to 2100 with prescribed varying $C_{a}$ were carried out with both model versions. For the future, $C_{a}$ concentrations corresponding to the SRESA1B scenario were used. Additional equilibrium simulations are carried out with a constant prescribed $C_{a}$ of $352 \mathrm{ppm}$, using climate forcing for the 1990s. These simulations allow to better assess the impact of $\mathrm{N}$ limitation on global NPP and carbon sequestration today.

\section{Results}

\section{1. $\mathrm{FACE}_{\mathrm{P}} \mathrm{CO}_{2}$ enrichment experiment at Duke Forest}

The main result of the $\mathrm{FACE}_{\mathrm{P}} \mathrm{CO}_{2}$ enrichment experiment at Duke Forest (Oren et al., 2001) was that at this moderately fertile site, the increase of annual carbon increment in woody tissue, following an artificial free-air $\mathrm{CO}_{2}$ enrichment by $200 \mathrm{ppm}$, was limited by nitrogen. The increase of annual carbon increment was only transient, and after three years, the soil $\mathrm{N}$ pool was depleted, so that the difference between treated and control plots vanished.

ORCHIDEE does not allow to properly simulate tree plantations. All forests are supposed to be natural, and thus the model structure does not allow to control the number of individuals per unit area. This creates problems when comparing hardwood in-

\section{Simple \\ parameterization of nitrogen limitation}

G. Krinner et al.

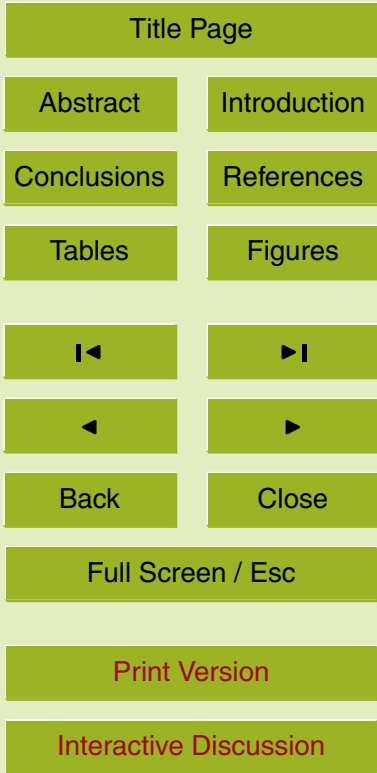

EGU 
creases in young forests to measurements in tree plantations, where new saplings do not establish, and therefore we decided to take simulated relative NPP changes as a surrogate for the measured relative differences in annual carbon increment in woody tissue. This is justified by the fact that biomass increase is commonly taken as a mea5 sure for NPP.

Figure 1 shows the simulated relative difference in annual-mean NPP between treated and untreated plots for both model versions. The measured relative increase of annual carbon increment in woody tissue, obtained by digitizing Fig. 1a of Oren et al. (2001), is also plotted in the figure. One can see that in the model version with 10 N limitation, the NPP increase due to the step increase in $C_{a}$, which is about $20 \%$ in the first year, vanishes in the third year. The model NPP decreases somewhat faster than the real one, indicating that the enhanced nitrogen limitation occurs too fast in the model, but the general trend is captured. In the model version without $\mathrm{N}$ limitation, the NPP increase also slightly weakens after a few years, but it does not vanish. Luo and 15 Reynolds (1999) and Luo (2001) give an explanation for the weakening of the NPP increase even in the absence of $\mathrm{N}$ limitation: After a step $\mathrm{CO}_{2}$ enrichment, photosynthesis immediately increases, and so does NPP. This enhanced NPP then leads to increased biomass and therefore to an increase in autotrophic respiration. This leads to partial reduction of the NPP increase. Because the biomass increase is not immediate, but a time-integrated consequence of the immediate GPP increase, there is a time lag between these two flux changes. Therefore, even in the absence of $\mathrm{N}$ limitation, the NPP increase following a step $\mathrm{CO}_{2}$ enrichment decreases after an initial maximum. This decrease is stronger in the model version with $\mathrm{N}$ limitation, as there is a second effect reducing NPP after the initial GPP increase: the enhanced NPP is not compensated by an immediate increase in soil heterotrophic respiration, leading to reduced $\mathrm{N}$ availability and thus to reduced productivity.

This difference in model behavior appears clearly in the annual GPP (not shown). Relative GPP increase vanishes after a few years when $\mathrm{N}$ limitation is taken into account, while it does not decrease in the opposite case until the end of the experiment.
BGD

2, 1243-1282, 2005

\section{Simple \\ parameterization of nitrogen limitation}

G. Krinner et al.

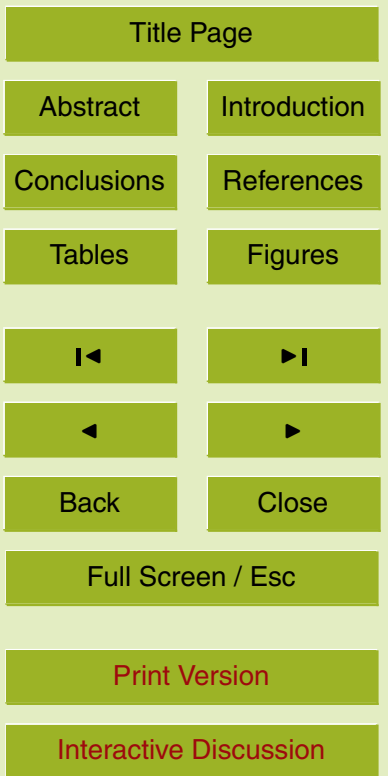

EGU 
Again, it is noteworthy that the simulated $\mathrm{N}$ limitation is fairly strong even in the control plots. This is due to the ongoing $\mathrm{CO}_{2}$ increase over the industrial period and the site history. At the $\mathrm{FACE}_{\mathrm{P}}$ site, significant soil $\mathrm{C}$ loss is simulated in the first years after a major disturbance (clear-cutting and re-plantation about 10 years before the 5 beginning of the $\mathrm{CO}_{2}$ enrichment experiment).

\subsection{FACE $\mathrm{CO}_{2}$ enrichment experiment at Oak Ridge}

The main result of this experiment was that NPP increased by $21 \%$ in the sweetgum stands exposed to elevated $C_{a}$ without loss of response over time during the 3 years of $\mathrm{CO}_{2}$ enrichment. Figure 2 displays displays the measured and simulated relative

10 NPP increase caused by $\mathrm{CO}_{2}$ fertilization. Norby et al. (2002) state that the measured temporal variations of NPP difference between treated and control plots during the three years of the experiment do not allow to conclude on a loss of response in time. This means that progressive nitrogen limitation did not occur during the three years of the experiment. The simulated $\mathrm{CO}_{2}$ fertilization effect is identical in both model versions 15 (with/without $\mathrm{N}$ limitation) during the first four years. The reason is that, in the version with $\mathrm{N}$ limitation, the simulated $\mathrm{N}$ availability $a_{N}$ is equal to 1 at the beginning of the simulated FACE experiment, and it falls below 1 only afterwards. This model behaviour contrasts to the Duke Forest simulations, where $\mathrm{N}$ limitation occurred fairly fast, both in model and reality. One reason is that the FACE $\mathrm{CO}_{2}$ enrichment experiment at Oak 20 Ridge was carried out somewhat earlier after the plantation was established (9 years) than was the case at Duke forest (11 years). Soils lose carbon during the first years after a plantation is established, because litterfall is lower than in a grown-up forest, and this leads to a reduction of $\mathrm{N}$ mineralization rates, and thus stronger $\mathrm{N}$ limitation, with time. A second reason is that the Duke forest experiment took place in a plantation of loblolly pines, which are needleleaf trees, while the Oak Ridge site is a sweetgum (that is, broadleaf summergreen) plantation with better litter quality and quantity, leading to higher soil heterotrophic respiration, and thus higher $\mathrm{N}$ mineralization rates, and less severe $\mathrm{N}$ limitation.

\section{Simple parameterization of nitrogen limitation}

G. Krinner et al.

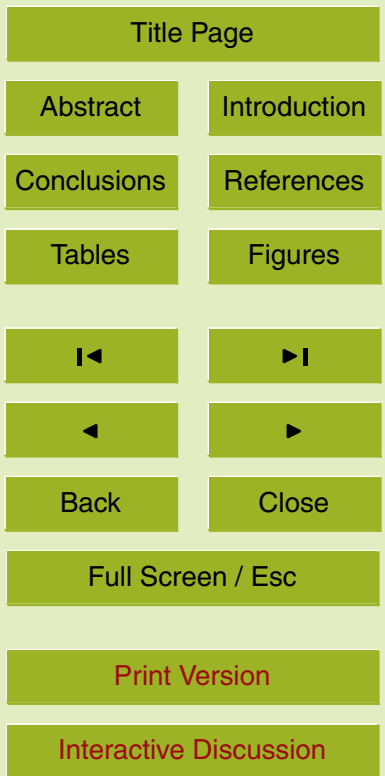


After the fourth year of the model experiment, $\mathrm{N}$ limitation occurs also at the Oak Ridge site, leading to reduced $\mathrm{CO}_{2}$ fertilization in the model version with $\mathrm{N}$ limitation. Unfortunately, NPP data for the years after 2000 are not yet available.

\subsection{Harvard soil warming experiment}

5 The main result of the Harvard soil warming experiment (Melillo et al., 2002) was that, although soil warming accelerated soil organic matter decay, the increased soil carbon release was transient because soil warming increased the availability of mineral nitrogen to plants, and thus stimulated $\mathrm{CO}_{2}$ uptake. Average yearly $\mathrm{CO}_{2}$ fluxes from the two types differed strongly only during the first year of the treatment, and are almost identical after 5 years or so.

Figure 3 displays the observed and simulated relative change of the total ecosystem $\mathrm{CO}_{2}$ flux caused by soil heating. It shows that when $\mathrm{N}$ limitation is not taken into account, soil warming leads to greatly increased $\mathrm{C}$ release in the model (initially up to $100 \%$, then about $40 \%$ during the second half of the first decade). In a longer simula15 tion (not shown), the labile soil $\mathrm{C}$ pool essentially attains a new equilibrium after about 30 years; the subsequently persisting weaker $C$ release is due to slightly enhanced decomposition of the more stable soil $\mathrm{C}$ pools.

When $\mathrm{N}$ limitation is taken into account, the model response is similar to these observations, and the mechanisms are those described by Melillo et al. (2002), as will be shown in the following. The simulated strong $C$ release is then essentially limited to the first few years. As in the observations, the increased soil $C$ release (black curve in Fig. 4) caused by the heating is then largely compensated by a NPP increase (red curve in Fig. 4) of almost the same magnitude. This NPP increase is due to the increased soil heterotrophic respiration which induces increased $\mathrm{N}$ availability, as can be

\section{BGD}

2, 1243-1282, 2005

\section{Simple \\ parameterization of nitrogen limitation}

G. Krinner et al.

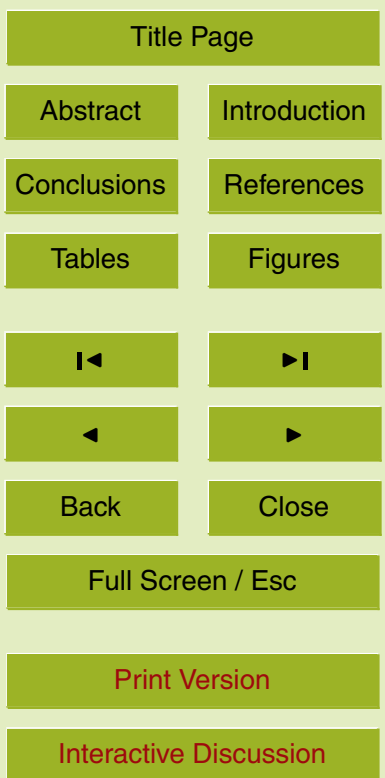

EGU 
The observed relative $\mathrm{CO}_{2}$ flux increase during the first year is about $40 \%$, while the model (with $\mathrm{N}$ limitation) simulates an increase of almost $100 \%$. After this first year, the modified model simulates the relative $\mathrm{CO}_{2}$ flux increase quite realistically. This means that, contrary to the simulations for the $\mathrm{FACE}_{\mathrm{P}}$ experiment, where enhanced $\mathrm{N}$ 5 limitation occurs too fast after the $C_{a}$ increase, it appears that in the simulations for the Harvard soil warming experiment, the $\mathrm{N}$ limitation reacts too slowly in the model.

The significant $\mathrm{N}$ limitation simulated by the model (Fig. 5) is due to two factors. First, soil carbon is not in equilibrium because of the agriculture in the 19th century. The carbon loss which occurred during this period is not yet compensated by the end of the 10 20th century, so that the heterotrophic respiration is lower than the NPP. Second, the $C_{a}$ increase since 1800 also leads to ongoing carbon sequestration in the ecosystem, meaning that NPP exceeds soil heterotrophic respiration. The same effect is visible in the other site simulations and in the transient global simulations.

\subsection{Global simulations}

15 Figure 6 displays the annual mean simulated global natural, and natural plus agricultural, NPP from 1800 to 2100 from the transient simulations for both model versions. In addition, values of total natural NPP for certain specific decades are listed in Table 1. From the preindustrial period to the 1990s, the relative NPP increase is $32 \%$ without $\mathrm{N}$ limitation, while it is only $19 \%$ in the modified model version. When, in addition to 20 the natural surfaces, agricultural surfaces are taken into account, the relative difference between the two model versions is weaker (see Fig. 6). The reason is that agricultural NPP increases equally (and quite strongly) in both model versions because the model supposes that there is no nitrogen limitation on agricultural ground.

The simulated natural equilibrium NPP at $C_{a}=352 \mathrm{ppm}$ and under the 1990s' cli25 mate is $48.5 \mathrm{GtC}$ with $\mathrm{N}$ limitation and $49.8 \mathrm{GtC}$ without; the natural NPP simulated in the transient simulations for the 1990s, during which the prescribed $C_{a}$ was close to $352 \mathrm{ppm}$, was $42.5 \mathrm{GtC} /$ year (with $\mathrm{N}$ limitation) and $48.6 \mathrm{GtC} /$ year (without). This means that, compared to the corresponding 352 ppm equilibrium simulation, the tran-

\section{BGD}

2, 1243-1282, 2005

\section{Simple parameterization of nitrogen limitation}

G. Krinner et al.

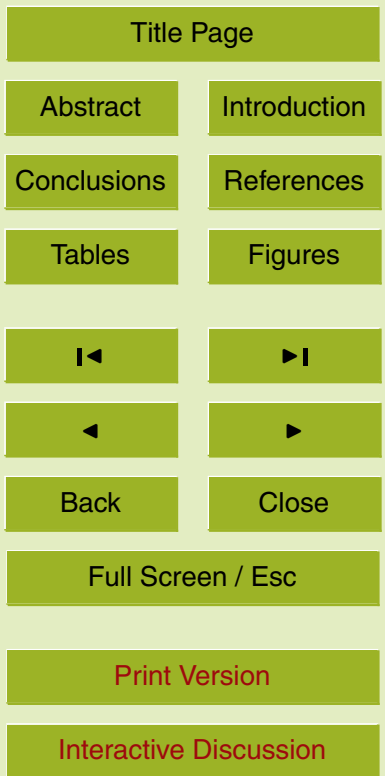

EGU 
sient model run with $\mathrm{N}$ limitation shows is a clear effect of $\mathrm{N}$ limitation on the global scale, leading to lower than equilibrium NPP. Compared to the $35.7 \mathrm{GtC}$ for the preindustrial "equilibrium" run, the transient simulation with $\mathrm{N}$ limitation yields a $19 \%$ increase between preindustrial times and 1990 (as stated before), while the correspond5 ing "equilibrium" NPP change is $36 \%$ (from 35.7 to $48.5 \mathrm{GtC}$ ). In the model version without N limitation, "equilibrium" and "transient" NPP at $C_{a}=350 \mathrm{ppm}$ are the same.

The global terrestrial biosphere is thought to have taken up 1.9 (from -0.3 to 3.8) GtC per year in the 1980s as residual sink (net of land-use change) as a consequence of the increase of $C_{a}$ since the beginning of the industrial period (IPCC, 2001). The reason for 10 this uptake is the slow response of the heterotrophic respiration to the NPP increase, and it is this imbalance between NPP and heterotrophic respiration that causes major $\mathrm{N}$ limitation to be simulated by the model (see Fig. 7). During the 20th century, the simulated $\mathrm{N}$ limitation is particularly strong in the high latitudes and in the equatorial forests. In the boreal regions, the strong $\mathrm{N}$ limitation is in part caused by the model 15 formulation which limits the quantity of decomposable organic carbon in the presence of soil freezing - this was, as stated before, one of the motivations of this work - , and it is in part caused by the increased $C_{a}$. However, the simulated boreal $\mathrm{N}$ limitation decreases towards the end of the 20th century due to simulated warming, which leads to enhanced decomposition of organic matter. In the equatorial forests, the particularly strong $\mathrm{N}$ limitation occurs because in the dominant PFT (tropical broadleaf evergreen trees) responds particularly strongly to increasing $C_{a}$.

The simulated decadal-mean terrestrial residual carbon sink for the $1980 \mathrm{~s}$ is 5.9 $\mathrm{GtC} / \mathrm{yr}$ without $\mathrm{N}$ limitation and $4.1 \mathrm{GtC} / \mathrm{yr}$ with $\mathrm{N}$ limitation. However, the interannual and decadal variability of this flux is quite high; the corresponding thirty-year means centered around 1985 are $5.0 \mathrm{GtC} / \mathrm{yr}$ and $3.3 \mathrm{GtC} / \mathrm{yr}$, respectively. This means that without $\mathrm{N}$ limitation, the simulated terrestrial residual carbon is overestimated, while it is at the upper limit of current estimates when $\mathrm{N}$ limitation is parameterized. In the model version with $\mathrm{N}$ limitation, a non-negligible $\mathrm{C}$ sink is simulated at "equilibrium" because the model was deliberately formulated so that organic carbon can accumu-

BGD

2, 1243-1282, 2005

\section{Simple parameterization of nitrogen limitation}

G. Krinner et al.

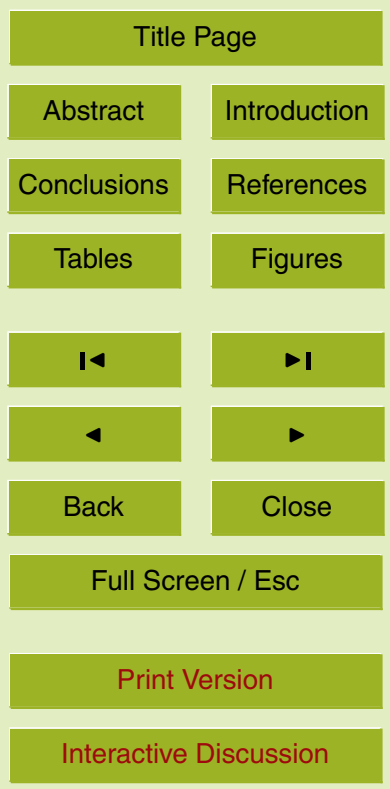

EGU 
late in the high latitudes (see Sect. 2). This is a realistic model feature, as it is well known that organic carbon does indeed accumulate in many boreal ecosystems. This carbon sink operates since longer than the industrial period, and, as stated before, enormous amounts of organic matter have accumulated in these regions (Stokstad, 5 2004). However, the natural preindustrial strength of this carbon sink is unknown. The "equilibrium" model sink for the preindustrial is a little less that $0.6 \mathrm{GtC} /$ year. Substracting this sink from the simulated global terrestrial carbon sink for the period 1970 to 2000 , one obtains a carbon sink increase of $3.3 \mathrm{GtC} / \mathrm{yr}-0.6 \mathrm{GtC} / \mathrm{yr}=2.7 \mathrm{GtC} / \mathrm{yr}$ for the modified model, due to climate and $C_{a}$ change since the preindustrial period.

For the transient simulation with $\mathrm{N}$ limitation, Fig. 8 displays the net ecosystem production as a function of latitude and time. Significant carbon sinks starts to occur at the end of the 20th century in the equatorial rainforest regions and in the Northern midlatitudes, the equatorial sink exceeding the northern mid-latitude sink sink because of the strong increase in heterotrophic respiration in the latter regions. The latitudinal pattern of NEP partially reflects that of nitrogen limitation: strong $\mathrm{N}$ limitation is diagnosed where NPP exceeds heterotrophic respiration $R_{H}$, and the difference between NPP and $R_{H}$ is simply the definition of NEP. However, the strong $\mathrm{N}$ limitation in high northern latitudes does not show up in Fig. 8 because of the low productivity of the corresponding ecosystems.

Figure 9 displays the impact of nitrogen limitation on NEP as a function of latitude and time. Nitrogen limitation becomes globally very obvious around 1970 or so. The simulated impact in tropical regions is very strong in the second half of the 20th century. After 2050, the NEP difference in the two model versions is similar in boreal and equatorial regions. Given the fact that primary productivity is low in the high latitudes, the relative impact of $\mathrm{N}$ limitation on boreal NEP is fairly strong after 2000 .

\section{Simple
parameterization of
nitrogen limitation}

G. Krinner et al.

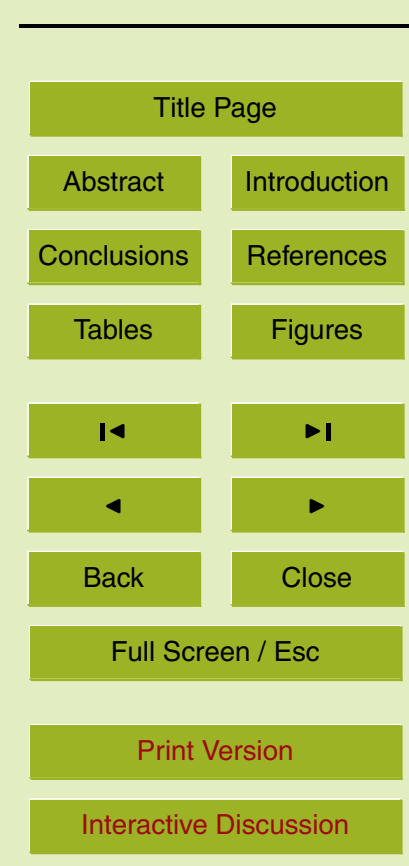

EGU 


\section{Discussion}

\subsection{Formulation of the scheme}

Nitrogen fertilization has lead to increased primary productivity in N-limited ecosystems in many field experiments. But the fundamental physiological mechanism leading

5 to reduced productivity in the presence of $\mathrm{N}$ limitation is not totally clear. Plants need nitrogen for photosynthesis, as reflected in the fact that $\mathrm{N}$ concentration is highest in leaves (Lousteau et al., 2001). The $\mathrm{CO}_{2}$ carboxylation enzyme rubisco contains a large fraction of this leaf nitrogen (Evans, 1989). Therefore, the $\mathrm{N}$ limitation is taken into account here by reducing the plants' photosynthetic capacity $V_{\max }$. However, some field experiments rather indicate that decreasing $\mathrm{N}$ supply decreases the rate of leaf expansion more than the rate of photosynthesis per unit leaf area (Petterson and McDonald, 1992). For the scope of this work, this uncertainty about the exact physiological effect underlying plant response to $\mathrm{N}$ limitation is not crucial, as long as the parameterization is able to represent the observed effect, including temporal dynamics, of $\mathrm{N}$ limitation on primary productivity.

In this scheme, heterotrophic respiration is limited by soil freezing. There are other factors limiting heterotrophic respiration in high latitudes, and in particular in permafrost regions. Some of these factors are: Decomposer activity is itself $\mathrm{N}$-limited (Mack et al., 2004); Northern ecosystems are frequently dominated by mosses, which give litter of extremely poor quality (Hobbie et al., 2000); and waterlogging, favored by soil freezing (Hobbie et al., 2000). These factors are not taken into account in the parameterization presented here. Therefore, this scheme is only a first step towards a better simulation of high latitude soil carbon dynamics, the only intention being to allow to represent $\mathrm{N}$ limitation on primary productivity in high latitudes.

25 Soil freezing and thawing, and the associated release and uptake of latent energy, is not yet taken in account in ORCHIDEE. A parameterization of soil water phase changes following Poutou et al. (2004) would allow to calculate more properly the position of the soil freeze and thaw fronts. Most plant-available nitrogen is derived from internal recy-
BGD

2, 1243-1282, 2005

\section{Simple parameterization of nitrogen limitation}

G. Krinner et al.

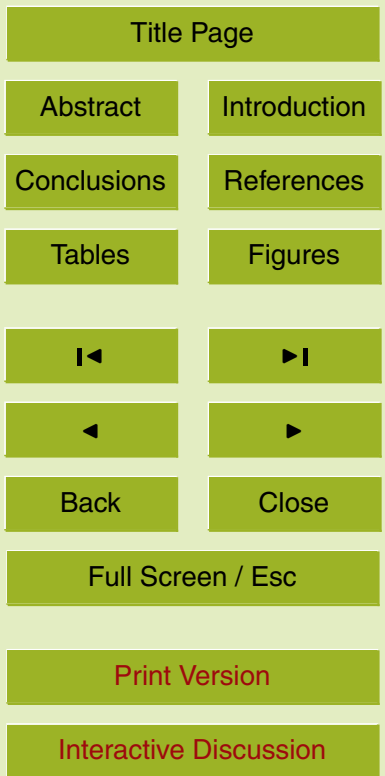

EGU 
cling (Schimel et al., 1997; Nadelhoffer et al., 1999). On a global scale, this internal recycling is at least an order of magnitude higher than the fluxes due to $\mathrm{N}$ deposition, biological fixation, leaching and gaseous loss (Vitousek and Howarth, 1991). Although Schimel et al. (1997) indicate that in steady state conditions, water/energy and nitro5 gen limitation will tend to "equilibrate" because carbon, water, and nitrogen fluxes are strongly correlated, external nitrogen sources and losses should be taken into in longterm steady state numerical experiments if nitrogen limitation is to be represented in a consistent manner. However, the aim of this work was to develop a scheme that allows to represent transient or progressive nitrogen limitation following a climate change or ${ }_{10} C_{a}$ increase (and, additionnally, the particularly strong $\mathrm{N}$ limitation in permafrost regions), and therefore the main focus was to represent progressive nitrogen limitation as discussed by Luo et al. (2004). Therefore, $\mathrm{N}$ deposition, biological fixation, leaching and gaseous loss are not accounted for in this simple scheme. Note that, in a way, "equilibrium" $\mathrm{N}$ limitation is taken into account implicitly in the model (both in the base-

15 line and the modified version) by setting the plants' maximum photosynthetic capacities lower than it would be in the case of optimum nitrogen availability.

\subsection{Degree of realism of the model results}

\subsubsection{Site experiments}

The model results compare fairly favourably with the site measurements obtained dur20 ing soil warming and $C_{a}$ fertilization experiments when $\mathrm{N}$ limitation is taken into account. The site experiments typically lasted for several (up to 10) years, and the model was able to represent the essential features of the observed soil and vegetation carbon dynamics (such as, for example, onset of strong $\mathrm{N}$ limitation after a few years of increased NPP in the FACE $_{\mathrm{P}} C_{a}$ enrichment experiment). However, it is obvious that 25 "real-world" climate and $C_{a}$ change do not occur as step functions, as in the field experiments and the simulations carried out here. Luo and Reynolds (1999) showed that the results of the field experiments must be interpreted very carefully in terms of future $C$

\section{Simple parameterization of nitrogen limitation}

G. Krinner et al.

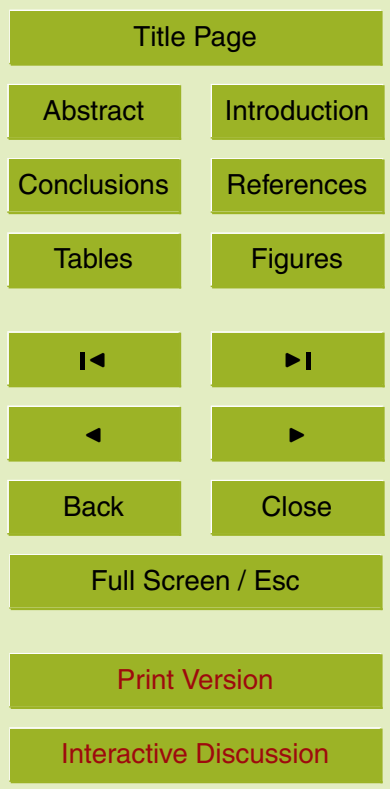


dynamics of ecysystems subject to climate change and/or $C_{a}$ increase. This, however, is not an issue here. The aim of the simulations was to test whether the modified model is able to correctly reproduce ecosystem $C$ dynamics under conditions of rapid climate and $C_{a}$ change.

5 5.2.2. Global simulations: Comparison with $\mathrm{C}$ sequestration and productivity data

Concerning the global simulations, the results of the simulations from the preindustrial period to today cannot easily be tested against measurements as our knowledge of C sequestration on the global scale is rather uncertain. Regional estimates of terrestrial C sequestration based on inverse atmospheric transport models (Fan et al., 1998;

10 Bousquet et al., 2000) point to a large carbon sink in the northern hemisphere extratropics. The results of these models are not too badly constrained in these regions because a large number of regular $C_{a}$ measurements are carried out there. But in the tropics and equatorial regions, no firm conclusions can be drawn from these models because the $C_{a}$ observation network is too sparse (Gurney et al., 2002). However, 15 long-term measurements of carbon balance in tropical regions (Phillips et al., 1998) show that South American equatorial forests have accumulated significant amounts of carbon in recent decades. The global simulations carried out with the modified model simulates large terrestrial carbon sequestration both in the northern hemisphere extratropics and in the Amazon region, and the global terrestrial carbon sink is on the high 20 end of current estimates.

One motivation for the development of this parameterization was the fact that Siberian forest productivity tends to be overestimated by ORCHIDEE. Goulden et al. (1998) showed that the boreal forst carbon balance is strongly influenced by soil freezing, with warm anonmies leading to strong carbon efflux from the soil. Nitrogen limi25 tation, caused by low net mineralization rates due to low soil temperatures, has often been reported to be a significant limiting factor on ecosystem primary productivity in boreal regions (Hobbie et al., 2002). It was therefore hoped that strong $\mathrm{N}$ limitation, caused by a significant phase lag between NPP and $R_{H}$ increases following indus-

\section{Simple parameterization of nitrogen limitation}

G. Krinner et al.

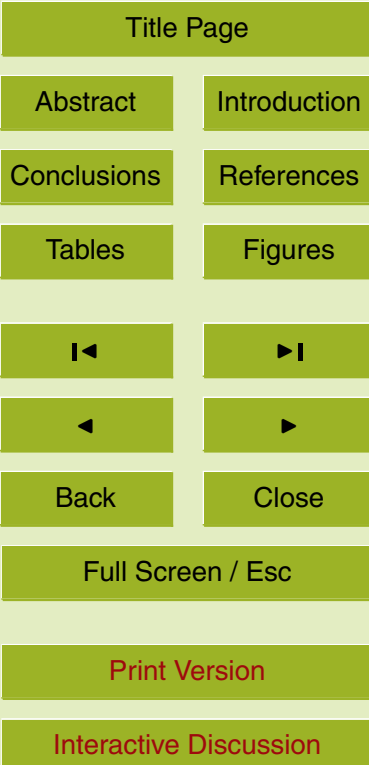


trial $\mathrm{CO}_{2}$ fertilization, would improve the model performance in this respect. However, the model does not show a very strong $\mathrm{N}$ limitation over the Siberian boreal forest belt in the transient run for the present (see Fig. 7). For the second half of the 20th century, the simulated Siberian boreal forest NPP decreases only by about $6 \%$ in the 5 transient run with $\mathrm{N}$ limitation compared to the run without limitation. Therefore, in these regions, the model still overestimates NPP roughly by a factor two compared to stand-level observations (Jarvis et al., 2001; Ciais et al., 2003) and forest biomass inventories (Shvidenko and Nilsson, 2003; Ciais et al., 2003). It is possible that the temperature dependence of soil respiration is not correctly represented in ORCHIDEE.

10 Another possible reason for this misfit are that boreal forest subsurface soil temperatures are not correctly calculated. Zimov et al. (1999) showed that moss layers, which are very frequent in boreal ecosystems, strongly reduce the soil thermal conductivity and thus reduce the active layer depth. This, in turn, leads to reduced heterotrophic respiration and thus to reduced nitrogen mineralization. This effect is not taken into 15 account in ORCHIDEE. Furthermore, ORCHIDEE does not represent the impact of soil freezing on the soil hydrology. Soil freezing often induces waterlogging, and thus reduced heterotrophic respiration (Hobbie et al., 2002). Further model development in this sense will be necessary to correct the overestimate of NPP in the boreal forest belt. With corrected, decelerated soil carbon turnover in the boreal forest regions, diagnosed nitrogen limitation during transient $C_{a}$ increase would become stronger.

In any case and as stated before, with the parameterization of $\mathrm{N}$ limitation presented here, the simulated global NEP for the present $(3.3 \mathrm{GtC} / \mathrm{yr})$ is at the upper limit of the range of current estimates of the real terrestrial sink net of land-use change $(-0.3$ to 3.8 GtC per year; IPCC, 2001). In the original model without $\mathrm{N}$ limitation, the present global NEP seems overestimated.

5.2.3. Global simulations: Comparison with other model results

Several intercomparison exercises designed to examine global vegetation model response to $\mathrm{CO}_{2}$ fertilization and/or climate change have been carried out in the recent

\section{Simple parameterization of nitrogen limitation}

G. Krinner et al.

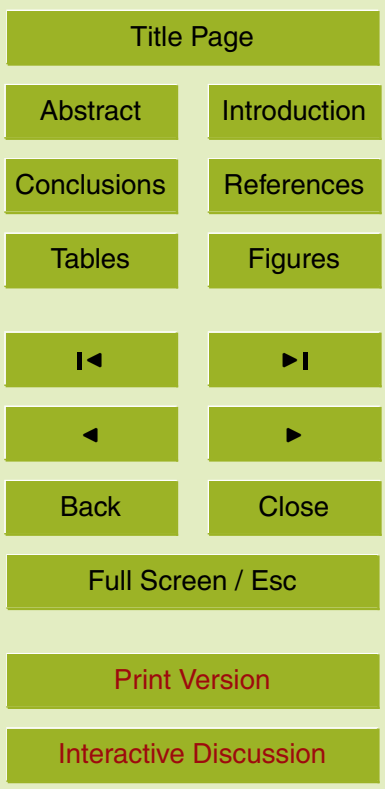


years (Kicklighter et al., 1999; Cramer et al., 2001). As stated before, simulated global NEP tended to be lower in the models which took nitrogen limitation into account (Kicklighter et al., 1999), similar to what was shown here. For a global $\mathrm{CO}_{2}$ fertilization experiment with projected climate change using six different vegetation models, Cramer 5 et al. (2001) reported, for the year 2100, a mean global NEP of $3.4 \mathrm{PgC} /$ year (range 0.3-6.6 PgC/year). The corresponding values for ORCHIDEE are 6.3 PgC/year in both model versions; ORCHIDEE yields thus results at the upper limit of the model range analyzed by Cramer et al. (2001). The time series of simulated global NEP (Fig. 10) is fairly similar to the mean mean response shown by Cramer et al. (2001, Fig. 4) in the 10 sense that the maximum global mean NEP is attained at about 2050 (Fig. 8). Afterwards, NEP decreases particularly in tropical regions, while it remains at high values in the boreal regions, similar to what Cramer et al. (2001) report for the models they analyzed. For 2100, Cramer et al. (2001) reported strong positive simulated NEP in the equatorial regions as well as in the northern mid and high latitudes. ORCHIDEE shows a very similar behaviour (see Fig. 8).

Supposing no change in the C:N ratio of trees (200) and soil (15), Hungate et al. (2003) have shown that most present-generation vegetation model yield terrestrial carbon stock increases between 2000 and 2100 which imply an additional nitrogen demand that exceeds estimated nitrogen supply limits. For simulations taking into account $C_{a}$ increase and climate change, the additional $\mathrm{N}$ required was between 2.3 and 16.9 petagrams of nitrogen $(\mathrm{PgN})$ Using the C:N ratios of Hungate et al. (2003), the global simulations presented here imply an additional $\mathrm{N}$ demand of $16.1 \mathrm{PgN}$ (with $\mathrm{N}$ limitation) and 17.5 PgN (without). As for most of the models examined by Hungate et al. (2003), this is more than the estimated upper nitrogen supply limit of $6.1 \mathrm{PgC}$. In other words, the modified model version seems to yield a bit more realistic results than the baseline model version, but it probably still overestimates the future carbon sink. However, it is noteworthy that even models with a complete prognostic $\mathrm{N}$ cycle yield carbon stocks increases that are not consistent with the projected maximum nitrogen supply limits.
BGD

2, 1243-1282, 2005

\section{Simple parameterization of nitrogen limitation}

G. Krinner et al.

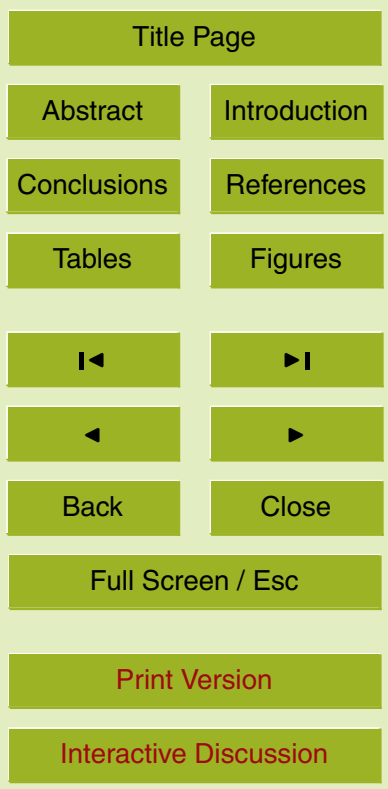

EGU 


\section{Conclusions}

The parameterization of nitrogen limitation presented here can be easily implemented in other vegetation models that do not dispose of a complete prognostic nitrogen cycle. The parameterization is not designed to make the nitrogen cycle in global vegetation 5 models unnecessary. It is rather designed to improve productivity and carbon sink estimates, in the context of climate change and variability, by models in which no such cycle is implemented yet.

The parameterization presented here allows to reproduce the essential features of observed carbon dynamics in soil warming and $\mathrm{CO}_{2}$ fertilization experiments. Estimated global NPP and NEP is reduced in $\mathrm{CO}_{2}$ fertilization experiments when the parameterization is active. But due to the large uncertainties concerning the present global terrestrial carbon sink, it is not possible to state with certainty that the modified model version yields more realistic results in this respect. The work of Hungate et al. (2003) suggests that even the modified model version underestimates the $\mathrm{N}$ limitation on global NPP in the next century. Rather than on such long timescales, this parameterization is therefore probably more adequate to improve model performance on interannual timescales, on which climate variability can induce significant short-term changes in plant productivity and soil respiration (e.g. Ciais et al., 2005).

Overestimated NPP in boreal forest areas was not sufficiently corrected with the implementation of the parameterization presented here, but the reason for this bias to subsist might actually lie in an inadequate parameterization of heterotrophic respiration in boreal soils. In this respect, it is worth noting that recent theoretical work indicates that labile and more stable soil carbon reservoirs might have different temperature sensitivities (Knorr et al., 2005). Taking these results into account might modify not but also, via nitrogen mineralization, projected future global primary productivity.

BGD

2, 1243-1282, 2005

\section{Simple parameterization of nitrogen limitation}

G. Krinner et al.

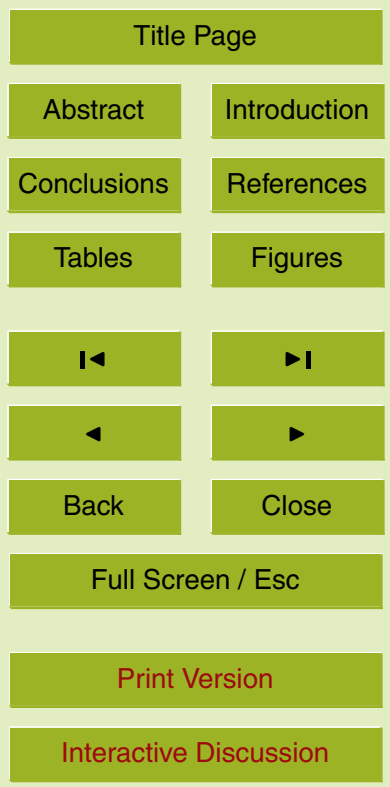

EGU 


\section{References}

Batjes, N. H.: Global Data Set of Derived Soil Properties, 0.5-Degree Grid (ISRIC-WISE), available online (http://www.daac.ornl.gov) from Oak Ridge National Laboratory Distributed Active Archive Center, Oak Ridge, Tennessee, USA, 2000. 1250

5 Bousquet, P., Peylin, P., Ciais, P., Le Quéré, C., Friedlingstein, P., and Tans, P.: Regional Changes in Carbon Dioxide Fluxes of Land and Oceans Since 1980, Science, 290, 13421346, 2000. 1263

Ciais, P., Janssens, I., Shvidenko, A., Wirth, C., Malhi, Y., Grace, J., Schulze, E., and Heimann, M.: Contrasted effects of rising $\mathrm{CO}_{2}$ on the uptake of carbon by tropical, temperate and boreal forest biomes, in: Carbon sinks in forest biomes, edited by Griffith, H., BIOS, 2003. 1264

Ciais, P., Reichstein, M., Viovy, N., Granier, A., Ogée, J., Allard, V., Buchmann, N., Aubinet, M., Bernhofer, C., Carrara, A., Chevallier, F., de Noblet, N., Friend, A., Friedlingstein, P., Grünwald, T., Heinesch, B., Keronen, P., Knohl, A., Krinner, G., Loustau, D., Manca, G., Matteucci, G., Miglietta, F., Ourcival, J., Pilegaard, K., Rambal, S., Seufert, G., Soussana, J., Sanz, M., Schulze, E., Vesala, T., and Valentini, R.: European-wide reduction in primary productivity caused by the heat and drought in 2003, Nature, in press, 2005. 1266

Cramer, W., Bondeau, A., Woodward, I. et al.: Global response of terrestrial ecosystem structure and function to $\mathrm{CO}_{2}$ and climate change: results from six dynamic global vegetation models, Glob. Ch. Biol., 7, 357-373, 2001. 1265

DeLucia, E., Hamilton, J., Naidu, S., Thomas, R., Andrews, J., Finzi, A., Laine, M., Matamala, R., Mohan, J., Hendrey, G., and Schlesinger, M.: Net primary productivity of a forest ecosystem with experimental $\mathrm{CO}_{2}$ enrichment, Science, 284, 1177-1179, 2004. 1245

Etheridge, D., Steele, L., Langenfelds, R., Francey, R., Barnola, J., and Morgan, V.: Historical $\mathrm{CO}_{2}$ records from the Law Dome DE08, DE08-2, and DSS ice cores, Carbon Dioxide Information Analysis Center, Oak Ridge National Laboratory, US Department of Energy, Oak Ridge, Tenn., USA, 1998. 1251

Evans, J.: Photosynthesis and nitrogen relationships in leaves of $\mathrm{C}_{3}$ plants, Oecologia, 78, 9-19, 1989. 1261

30 Fan, S., Gloor, M., Mahlmann, J., Pacala, S., Sarmiento, J., Takahashi, T., and Tans, P.: A large terrestrail carbon sink in North America implied by atmospheric and oceanic carbon dioxide data and models, Science, 282, 442-446, 1998. 1263

\section{Simple \\ parameterization of nitrogen limitation}

G. Krinner et al.

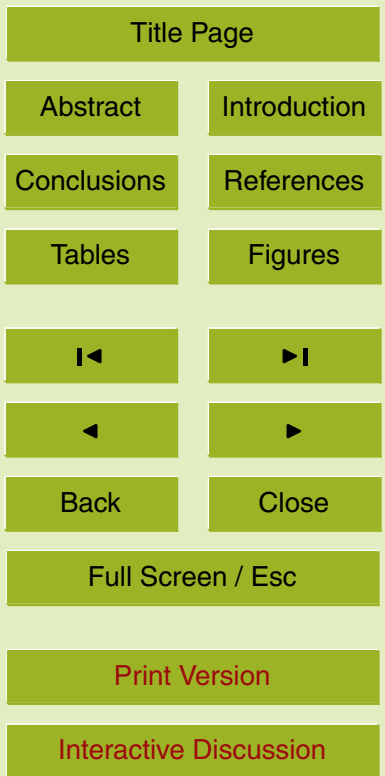

EGU 
Friend, A.: Parameterisation of a global daily weather generator for terrestrial ecosystem modelling, Ecological Modelling, 109, 121-140, 1998. 1251

Goulden, M., Wofsky, S., Harden, J., Trumbore, S., Crill, P., Gower, S., Fries, T., Daube, B., Fan, S., Sutton, D., Bazzaz, A., and Munger, J.: Sensitivity of boreal forest carbon balance to soil thaw, Science, 279, 214-217, 1998. 1263

Gurney, K., Law, R., et al.: Towards robust regional estimates of $\mathrm{CO}_{2}$ sources and sinks using atmospheric transport models, Nature, 415, 626-630, 2002. 1263

Hobbie, S., Schimel, J., Trumbore, S., and Randerson, J.: Controls over carbon storage and turnover in high-latitude soils, Glob. Ch. Biol., 6, 196-210, 2000. 1261

10 Hobbie, S., Nadelhoffer, K. J., and Högberg, P.: A synthesis: The role of nutrients as constraints on carbon balances in boreal and arctic regions, Plant and Soil, 242, 163-170, 2002. 1245, 1246, 1263, 1264

Hoosbeek, M., van Breemen, N., Berendse, F., Grosvernier, P., and Vasander, H.: Limited effect of increased atmospheric $\mathrm{CO}_{2}$ concentration on ombrotrophic bog vegetation, New

15 Phytologist, 150, 459-463, 2001. 1246

Hu, S., Chapin III, F., Firestone, M., Field, C., and Chiariello, N.: Nitrogen limitation of microbial decomposition in a grassland under elevated $\mathrm{CO}_{2}$, Nature, 409, 188-190, 2001. 1246

Hungate, B., Holland, E., Jackson, R., Chapin III, F., Mooney, H., and Field, C.: The fate of carbon in grasslands under carbon dioxide enrichment, Nature, 388, 576-579, 1997. 1246

20 Hungate, B., Dukes, J., Shaw, M., Luo, Y., and Field, C.: Nitrogen and Climate Change, Science, 302, 1512-1513, 2003. 1244, 1265, 1266

Hungate, B., Stiling, P., Dijkstra, P., Johnson, D., Ketterer, M., Hymus, G., Hinkle, C., and Drake, B.: $\mathrm{CO}_{2}$ elicits long-term decline in nitrogen fixation, Science, 304, 1291, 2004. 1247

IPCC: IPCC Third Assessment Report: Climate Change 2001 - The scientific basis, Cambridge

$25 \quad$ University Press, UK, 2001. 1244, 1259, 1264

Jarvis, P., Saugier, B., and Schulze, E.: Productivity of Boreal Forests, in Roy et al. (2001), 211-244, 2001. 1264

Keeling, C. and Whorf, T.: Atmospheric $\mathrm{CO}_{2}$ records from sites in the $\mathrm{SIO}$ air sampling network, Carbon Dioxide Information Analysis Center, Oak Ridge National Laboratory, US Department 30 of Energy, Oak Ridge, Tenn., USA, 2004. 1251

Kicklighter, D., Bruno, M., Dönges, S., Esser, G., Heimann, M., Helfrich, J., Ift, F., Joos, F., Kaduk, J., Kohlmaier, G., McGuire, A., Melillo, J., Meyer, R., Moore, B., Nadler, A., Prentice, I., Sauf, W., Schloss, A., Sitch, S., Wittenberg, U., and Würth, G.: A first-order analysis of

\section{Simple \\ parameterization of nitrogen limitation}

G. Krinner et al.

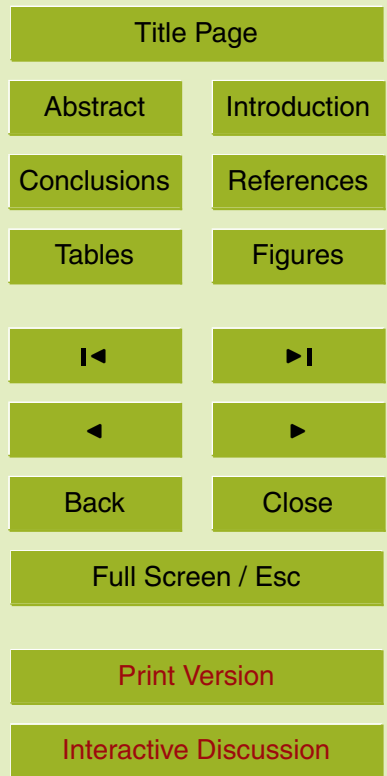

EGU 
the potential rôle of $\mathrm{CO}_{2}$ fertilization to affect the global carbon budget: a comparison of four terrestrial biosphere models, Tellus, 51, 343-366, 1999. 1244, 1265

Knorr, W., Prentice, I., House, J., and Holland, E.: Long-term sensitivity of soil carbon turnover to warming, Nature, 433, 298-301, 2005. 1266

5 Krinner, G., Viovy, N., de Noblet-Ducoudré, N., Ogée, J., Polcher, J., Friedlingstein, P., Ciais, P., Sitch, S., and Prentice, C.: A dynamic global vegetation model for studies of the coupled atmosphere-biosphere system, Glob. Biogeochem. Cyc., 19, GB1015, doi:10.1029/2003GB002199, 2005. 1247, 1248, 1252, 1254

Lousteau, D., Hungate, B., and Drake, B.: Water, Nitrogen, Rising atmospheric $\mathrm{CO}_{2}$, and terrestrial productivity, in Roy et al. (2001), 123-167, 2001. 1261

Loveland, T., Reed, B., Brown, J., Ohlen, D., Zhu, Z., Yang, L., and Merchant, J.: Development of a global land cover characteristics database and IGBP DISCover from $1 \mathrm{~km}$ AVHRR data, Int. J. Remote Sensing, 21, 1303-1330, 2000. 1254

Luo, Y.: Transient ecosystem responses to free-air $\mathrm{CO}_{2}$ enrichment (FACE): experimental ev15 idence and methods of analysis, New Phytologist, 152, 3-3, http://www.blackwell-synergy. com/links/doi/10.1046/j.0028-646X.2001.00247.x/abs, 2001. 1255

Luo, Y. and Reynolds, J.: Validity of extrapolating field $\mathrm{CO}_{2}$ experiments to predict carbon sequestration in natural ecosystems, Ecology, 80, 1568-1583, 1999. 1255, 1262

Luo, Y., Currie, W., Dukes, J., Finzi, A., Hartwig, U., Hungate, B., McMurtrie, R., Oren, R., Parton, W., Pataki, D., Shaw, M., Zak, D., and Field, C.: Progressive nitrogen limitation of ecosystem responses to rising atmospheric carbon dioxide, BioScience, 54, 731-739, 2004. 1245, 1247, 1262

Mack, M., Schuur, E., Bret-Harte, S., Shaver, G., and Chapin III, F.: Ecosystem carbon storage in arctic tundra reduced by long-term nutrient fertilization, Nature, 431, 440-443, 2004. 1246,1261

Melillo, J., Steudler, P., Aber, J., Newkirk, K., Lux, H., Bowles, F., Catricala, C., Magill, A., Ahrens, T., and Morrisseau, S.: Soil warming and carbon-cycle feedbacks to the climate system, Science, 298, 2173-2176, 2002. 1246, 1249, 1251, 1257

Nadelhoffer, K., Emmett, B., Gundersen, P., Kjonaas, J., Koopmans, C., Schlepp, P., Tietemann, 30 A., and Wright, R.: Nitrogen deposition makes a minor contribution to carbon sequestration in temperate forests, Nature, 398, 145-148, 1999. 1245, 1262

Neff, J., Townsend, A., Gleixner, G., Lehmann, S., Turnbull, J., and Bowman, W.: Variable effects of nitrogen additions on the stability and turnover of soil carbon, Nature, 419, 915-
BGD

2, 1243-1282, 2005

\section{Simple \\ parameterization of nitrogen limitation}

G. Krinner et al.

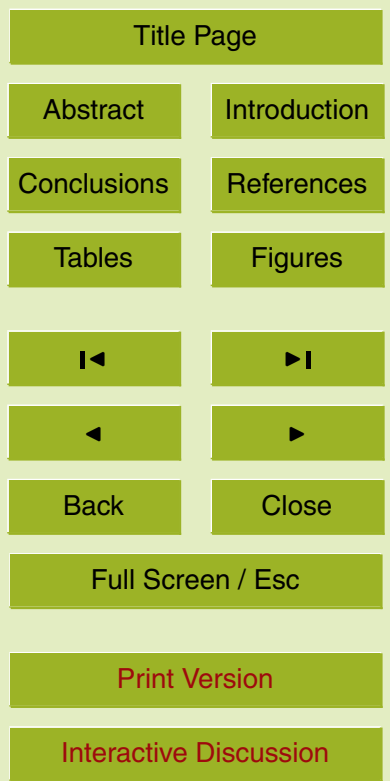

EGU 
New, M., Hulme, M., and Jones, P.: Representing Twentieth-Century Space-Time Climate Variability. Part I: Development of a 1961-90 Mean Monthly Terrestrial Climatology, J. Climate, 12, 829-856, 1999. 1252, 1253, 1254

5 Norby, R., Hanson, P., O’Neill, E., Tschaplinski, T., Weltzin, J., Hansen, R., Cheng, W., Wullschleger, S., Gunderson, C., Edwards, N., and Johnson, D.: Net primary productivity of a $\mathrm{CO}_{2}$-enriched deciduous forest and the implications for carbon storage, Ecological Applications, 12, 1261-1266, 2002. 1246, 1251, 1256

Oechel, W., Cowles, S., Grulke, N., Hastings, S., Lawrence, B., Prudhomme, T., Riechers, G., Strain, B., Tissue, D., and Vourlitis, G.: Transient nature of $\mathrm{CO}_{2}$ fertilization in Arctic tundra, Nature, 371, 500-503, 1994. 1246, 1249

Oren, R., Ellsworth, D., Johnsen, K., Phillips, N., Ewers, B., Maler, C., Schläfer, K., McCarthy, H., Hendrey, G., McNulty, S., and Katul, G.: Soil fertility limits carbon sequestration by forest ecosystems in a $\mathrm{CO}_{2}$-enriched atmosphere, Nature, 411, 469-472, 2001. 1245, 1249, 1251,

Parton, W., Stewart, J., and Cole, C.: Dynamics of C, N, P, and S in grassland soil: A model, Biogeochem., 5, 109-131, 1988. 1248

Petterson, R. and McDonald, A.: Effects of elevated carbon dioxideconcentration on photosynthesis and growth of small birch plants at optimal nutrition, Plant, Cell and Environ., 15, $20 \quad$ 911-919, 1992. 1261

Phillips, M., Malhi, Y., Higuchi, N., Laurance, W., Nuñez, P., Vásquez, R., Laureance, S., Ferreira, L., Stern, M., Brown, S., and Grace, J.: Changes in the carbon balance of tropical forests: Evidence from long-term polts, Science, 282, 439-442, 1998. 1263

Poorter, $\mathrm{H}$.: Interspecific variation in the growth response of plants to an elevated ambient carbon dioxide concentration, Vegetatio, 104/105, 77-97, 1993. 1247

Poutou, E., Krinner, G., Genthon, C., and de Noblet-Ducoudré, N.: Impact of soil freezing on future boreal climate change, Clim. Dyn., 23, 621-639, 2004. 1261

Richardson, C. and Wright, D.: A model for generating daily weather variables, Tech. rep., U.S. Dept. of Agriculture, Agric. Res. Serv., 1984. 1251

30 Roy, J., Saugier, B., and Mooney, H. (eds.): Terrestrial Global Productivity, Academic Press, 2001. 1268, 1269

Schimel, D., Braswell, B., and Parton, W.: Equilibration of the terrestrial water, nitrogen, and carbon cycles, Proc. Natl. Acad. Sci., 94, 8280-8283, 1997. 1245, 1247, 1262

\section{Simple parameterization of nitrogen limitation}

G. Krinner et al.

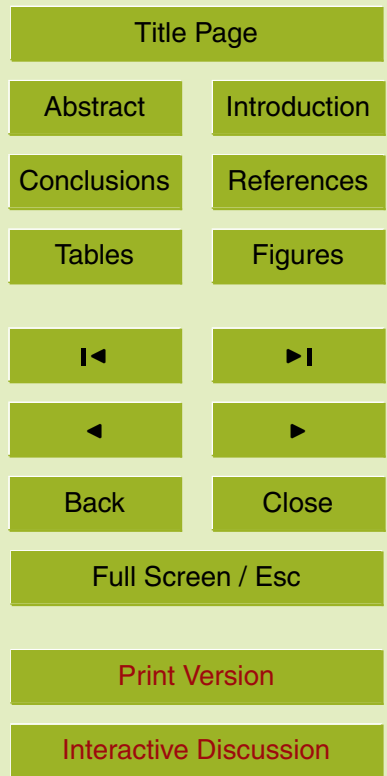

EGU 
Shvidenko, A. and Nilsson, S.: A synthesis of the impact of Russian forests on the global carbon budget for 1961-1998, Tellus, 55, 391-415, 2003. 1264

Stokstad, E.: Defrosting the carbon freezer of the North, Science, 304, 1618-1620, 2004. 1249, 1260

5 Vitousek, P. and Howarth, R.: Nitrogen limitation on land and in the sea: How can it occur?, Biogeochemistry, 13, 87-115, 1991. 1245, 1249, 1262

Zimov, S., Davidov, S., and Voropaev, Y.: Siberian $\mathrm{CO}_{2}$ efflux in winter as a $\mathrm{CO}_{2}$ source and cause of seasonality in atmospheric $\mathrm{CO}_{2}$, Climatic Change, 33, 111-120, 1996. 1250

Zimov, S., Davidov, S., Zimova, G., Davidova, A., Chapin III, F., Chapin, M., and Reynolds, J.: Contribution of distrubance to increasing seasonal amplitude of atmospheric $\mathrm{CO}_{2}$, Science, 284, 1973-1976, 1999. 1264

BGD

2, 1243-1282, 2005

\section{Simple parameterization of nitrogen limitation}

G. Krinner et al.

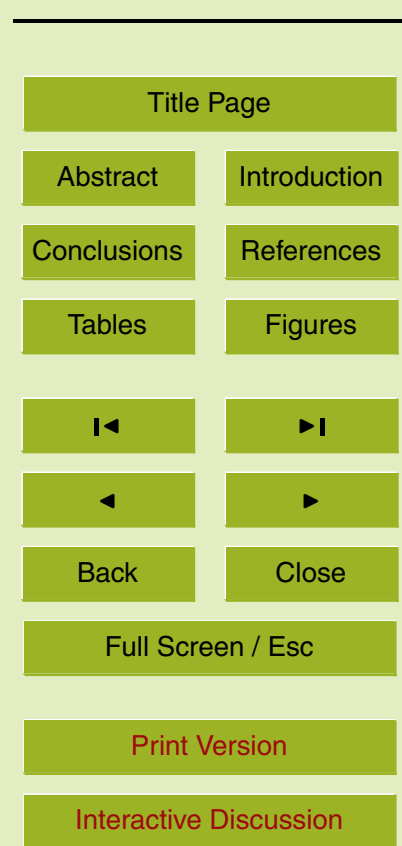

EGU 
2, 1243-1282, 2005

\section{Simple parameterization of nitrogen limitation}

G. Krinner et al.

Table 1. Simulated NPP (in GtC/year) for natural vegetation. NL: without nitrogen limitation; L: with nitrogen limitation.

\begin{tabular}{cllll}
\hline Simulation type & $\mathrm{CO}_{2}$ & Decade & NPP (NL) & NPP (L) \\
\hline Equilibrium & $284 \mathrm{ppm}$ & $1800 \mathrm{~s}$ & 36.9 & 35.7 \\
Transient & Varying & $1990 \mathrm{~s}$ & 48.6 & 42.5 \\
Equilibrium & $352 \mathrm{ppm}$ & $1990 \mathrm{~s}$ & 49.8 & 48.5 \\
\hline
\end{tabular}

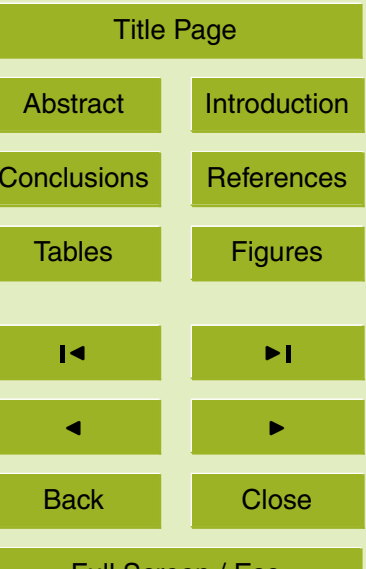

Full Screen / Esc

Print Version

Interactive Discussion 


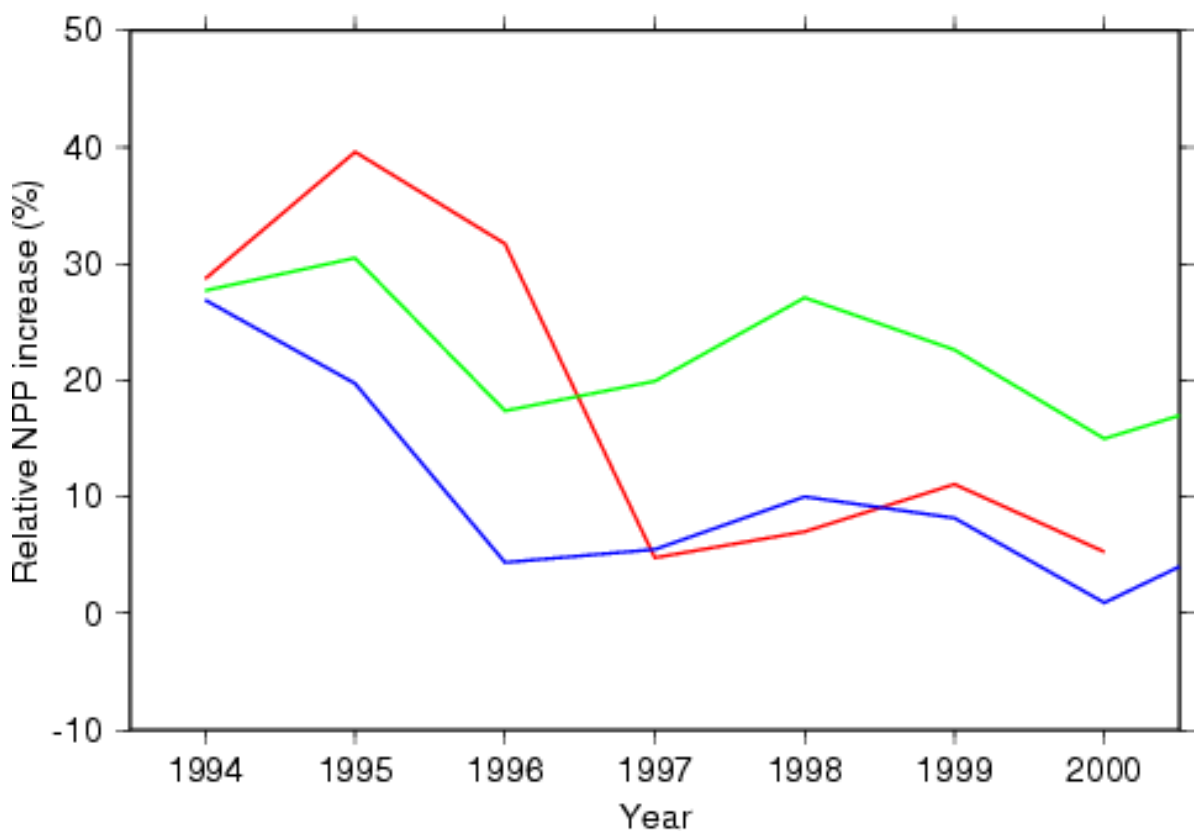

Fig. 1. FACE $C_{\mathrm{P}} C_{a}$ enrichment experiment at Duke Forest: Relative change of simulated NPP (12-month moving average, \%), and measured relative change of carbon increment in woody tissue (annual, \%), both due to $\mathrm{CO}_{2}$ enrichment.

\section{Simple parameterization of nitrogen limitation}

G. Krinner et al.

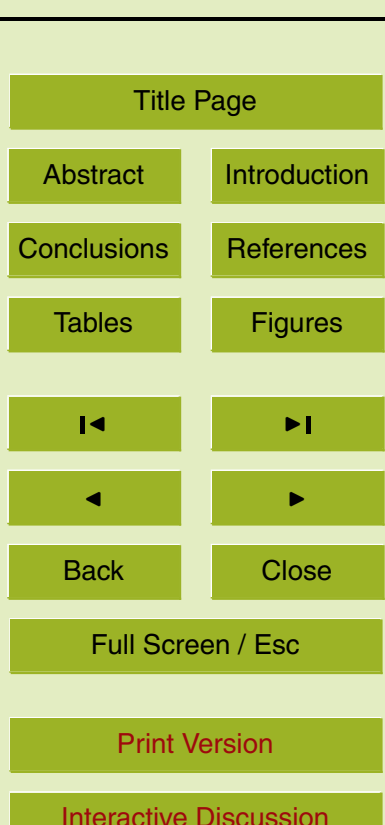

EGU 


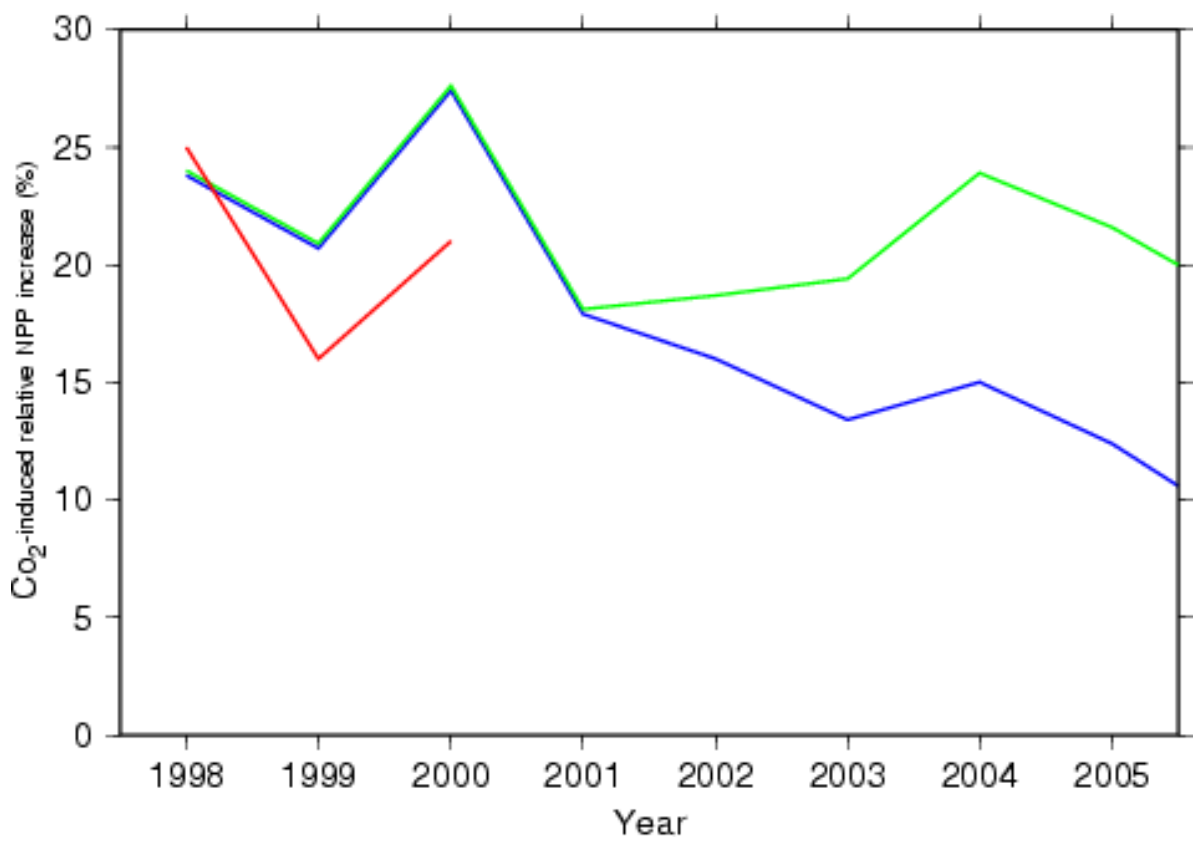

Fig. 2. $\mathrm{FACE}_{\mathrm{P}} \mathrm{CO}_{2}$ enrichment experiment at Oak Ridge: Relative increase (\%) of observed and simulated annual mean NPP due to $\mathrm{CO}_{2}$ enrichment. Red: Observations; Green: Without $\mathrm{N}$ limitation; Blue: With $\mathrm{N}$ limitation. Values for the blue and green curves are identical during the first 4 years; the blue curve has been shifted downwards by $0.2 \%$ to improve readability.

\section{Simple parameterization of nitrogen limitation}

G. Krinner et al.

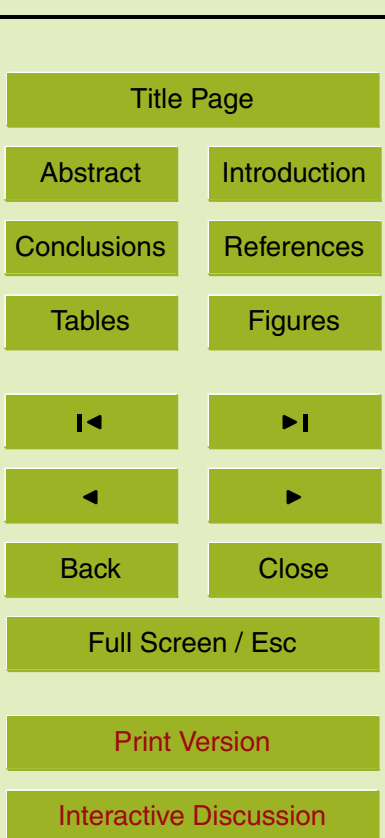

EGU 


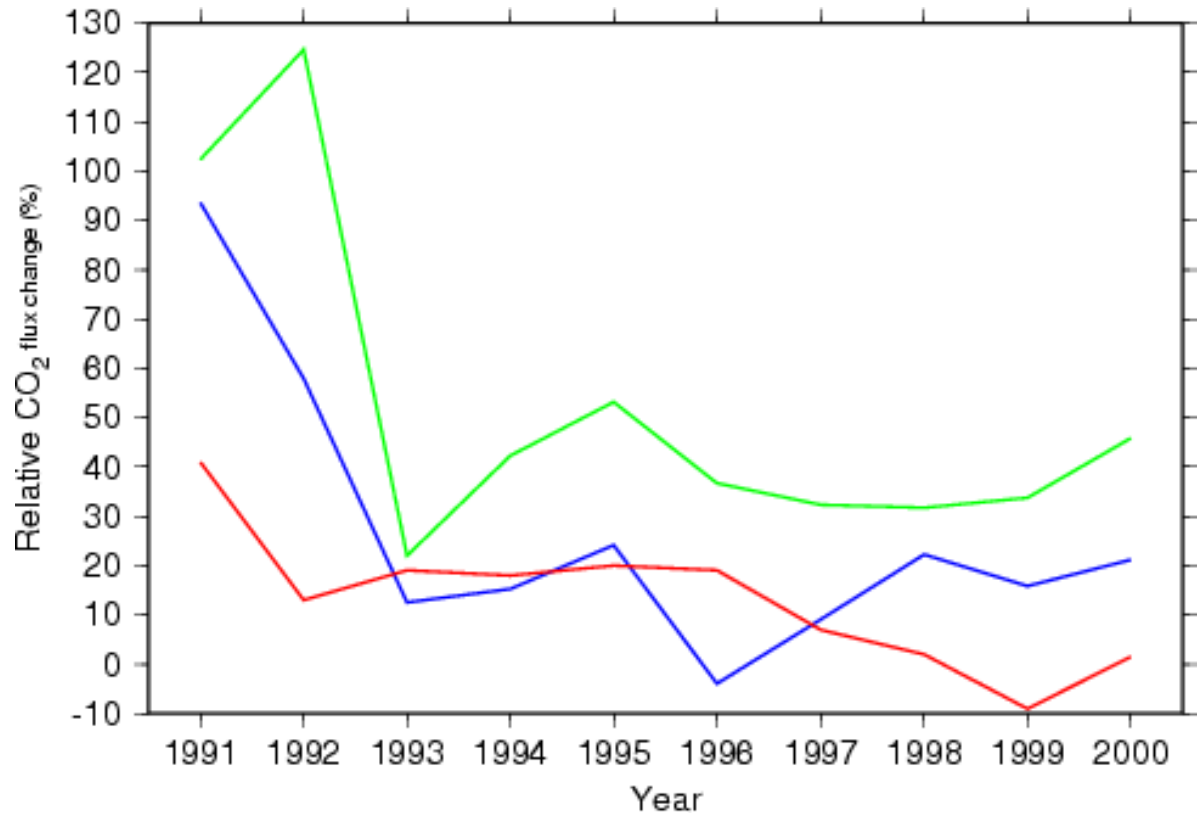

Fig. 3. Harvard soil warming experiment: Impact of soil heating on the total ecosystem $\mathrm{CO}_{2}$ flux. relative difference (\%) between the heated and control plots. Red: Observations; Green: Without $\mathrm{N}$ limitation; Blue: With $\mathrm{N}$ limitation.

\section{Simple parameterization of nitrogen limitation}

G. Krinner et al.

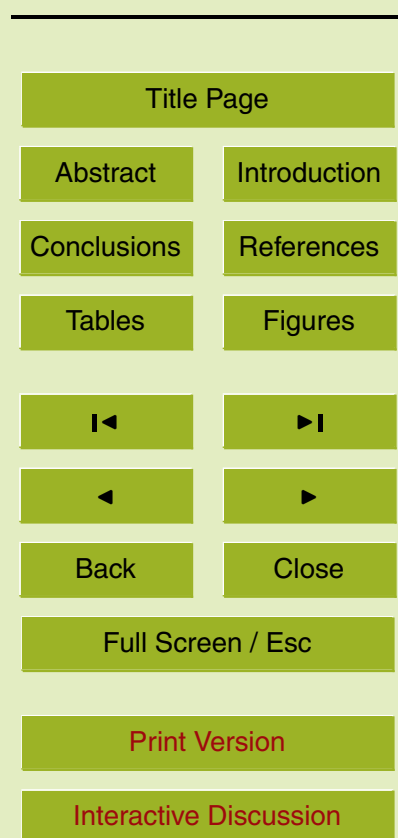

EGU 


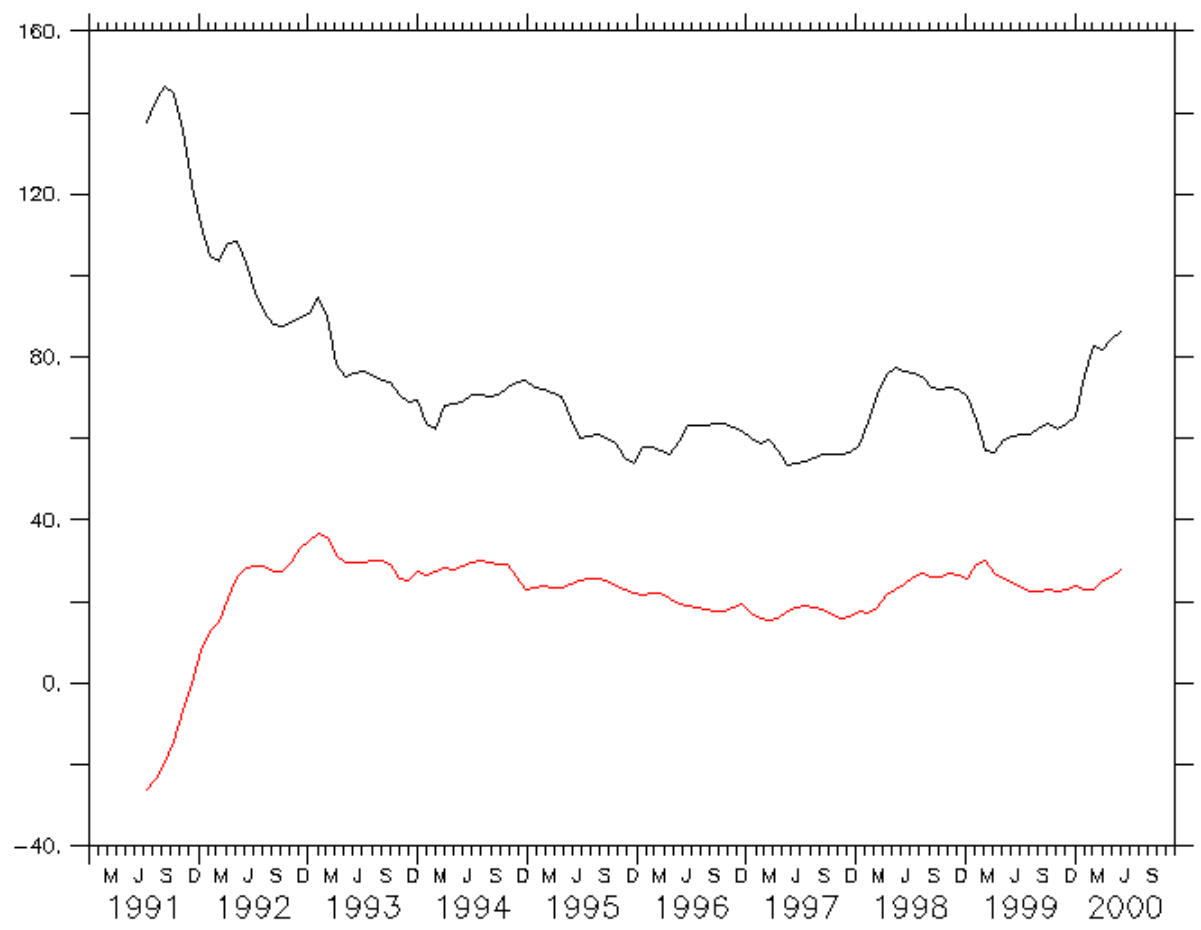

Fig. 4. Harvard soil warming experiment: Impact of soil heating on the simulated ecosystem $\mathrm{CO}_{2}$ flux components in the model version with $\mathrm{N}$ limitation (12-month moving average, $\mathrm{gC} / \mathrm{m}^{2} /$ year). Difference between treated and control plots. Black: Difference in soil heterotrophic respiration $\left(R_{H}\right)$; red: Difference in NPP.
2, 1243-1282, 2005

\section{Simple parameterization of nitrogen limitation}

G. Krinner et al.

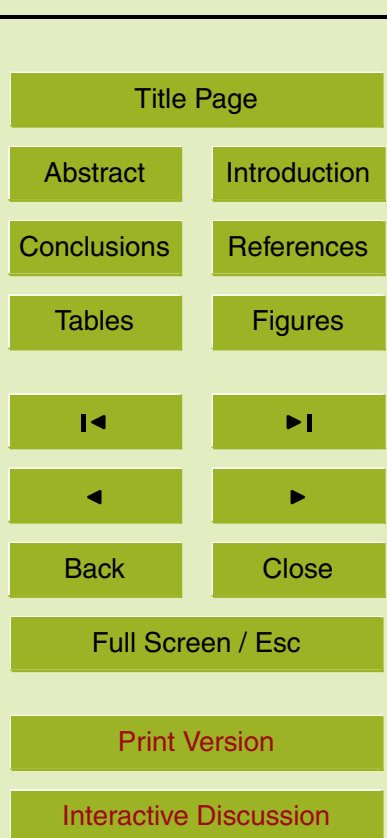

EGU 


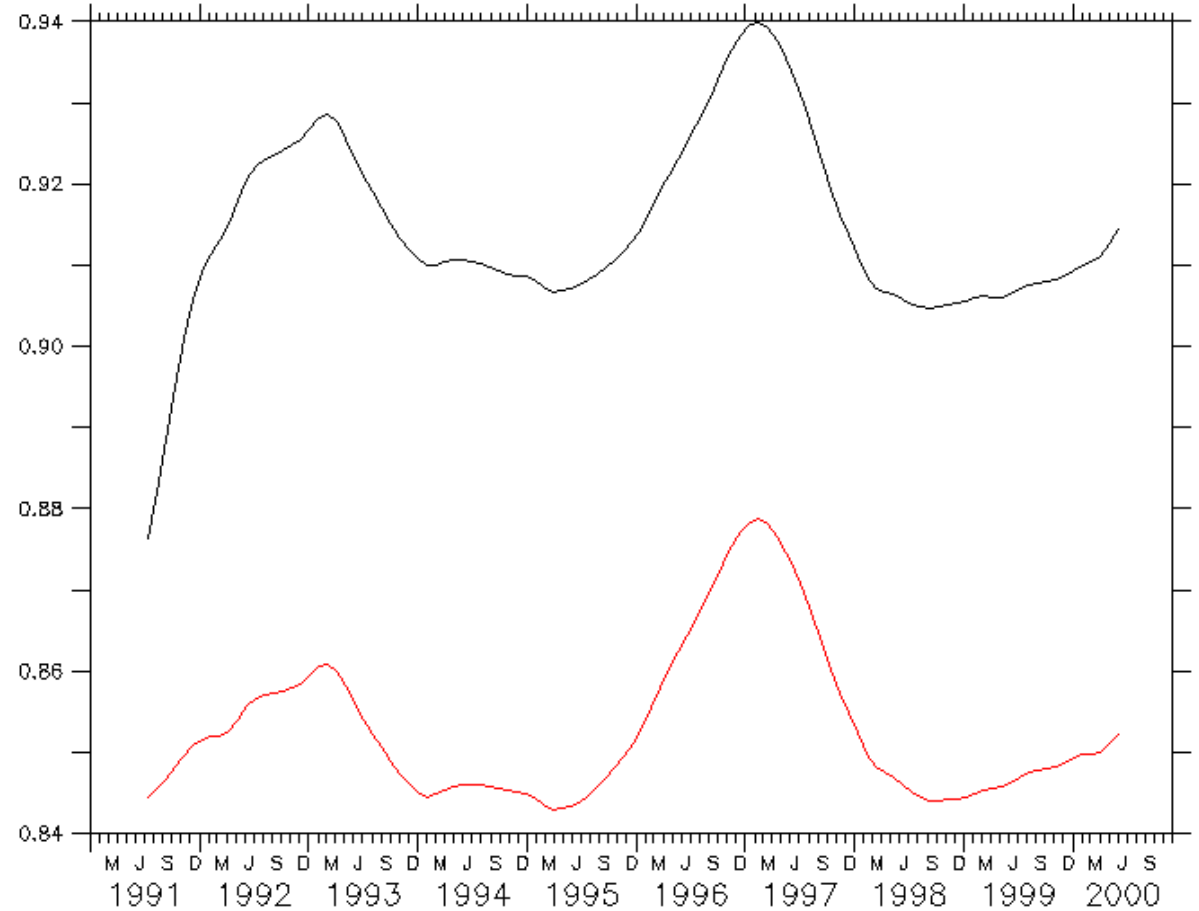

Fig. 5. Harvard soil warming experiment: Simulated $\mathrm{N}$ availability in the simulation with $\mathrm{N}$ limitation (12-month moving average, dimensionless). Black: with soil heating; red: without soil heating.

\section{Simple parameterization of nitrogen limitation}

G. Krinner et al.

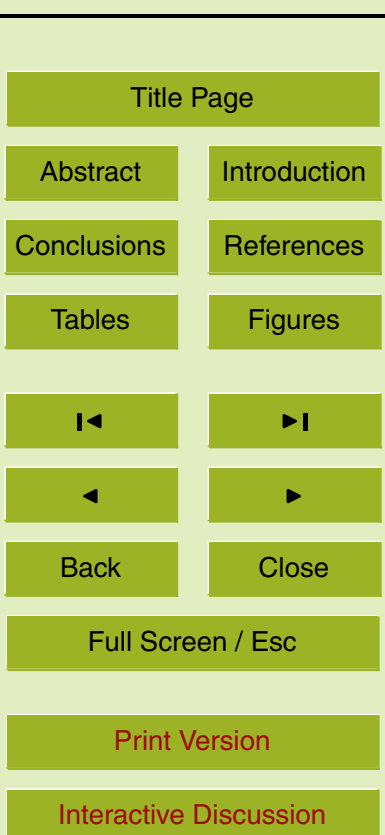

EGU 


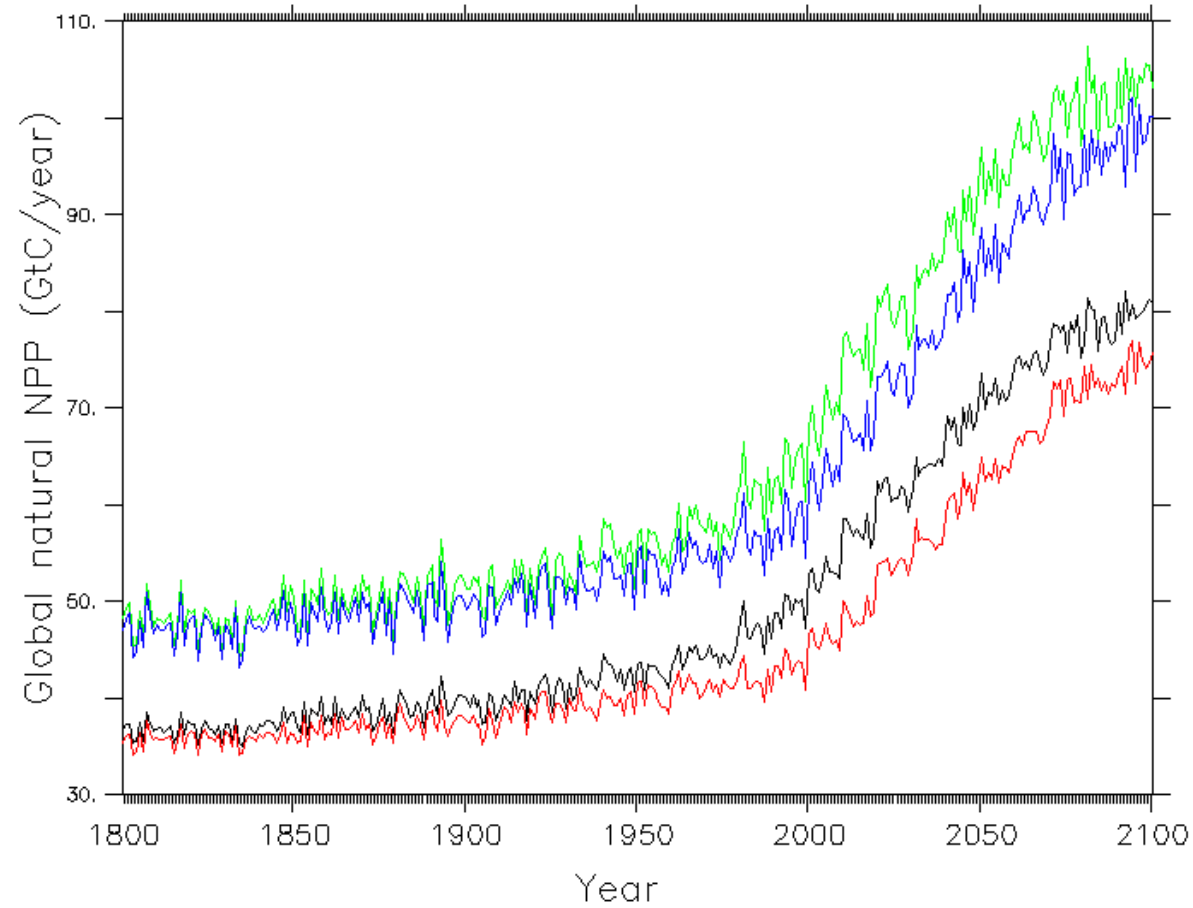

Fig. 6. Global simultion: Simulated global NPP from 1800 to 2100 (GtC/year). Black: without N limitation, natural vegetation only; red: with $\mathrm{N}$ limitation, natural vegetation only; green: without $\mathrm{N}$ limitation, all surfaces; blue: with $\mathrm{N}$ limitation, all surfaces.

\section{Simple parameterization of nitrogen limitation}

G. Krinner et al.

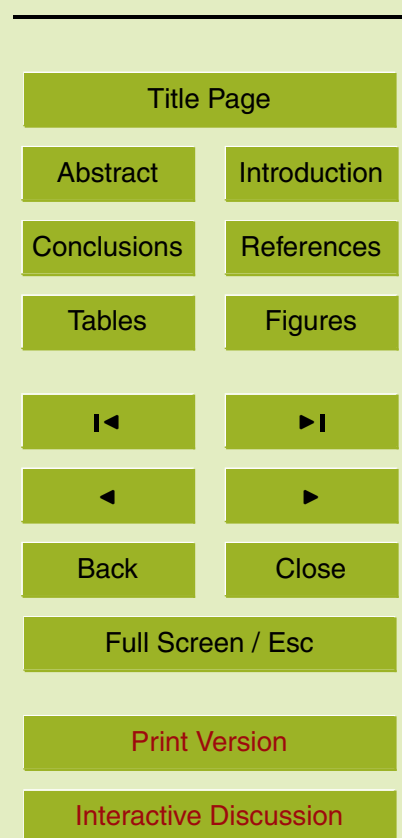

EGU 
BGD

2, 1243-1282, 2005

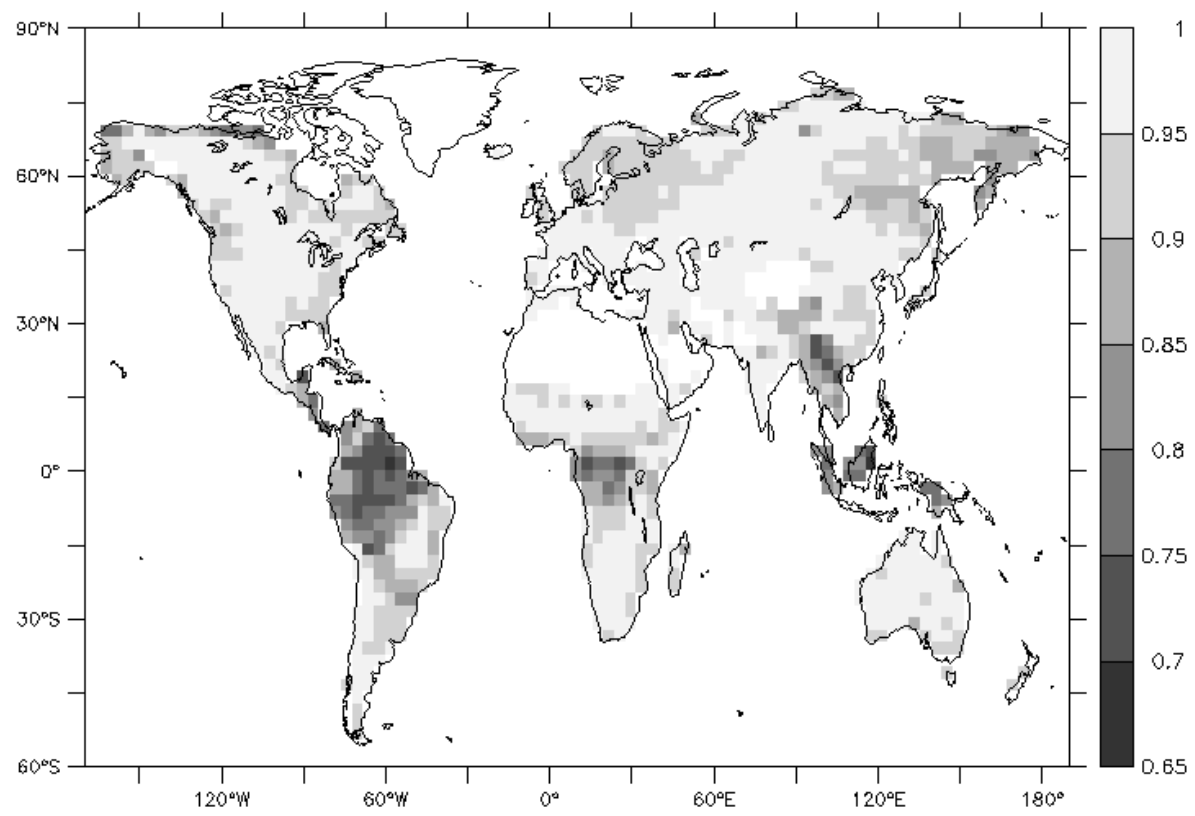

Simple parameterization of nitrogen limitation

G. Krinner et al.

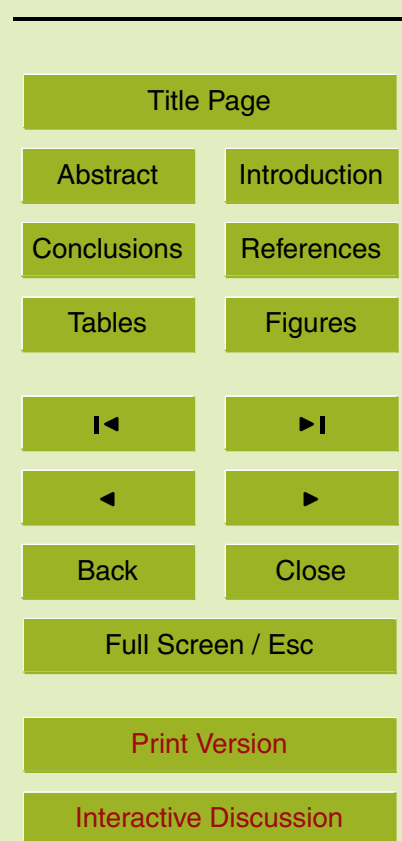

EGU

Fig. 7. Simulated nitrogen availability $a_{N}$ (Eq. 2) for the 1990s in the transient simulation with nitrogen limitation. 


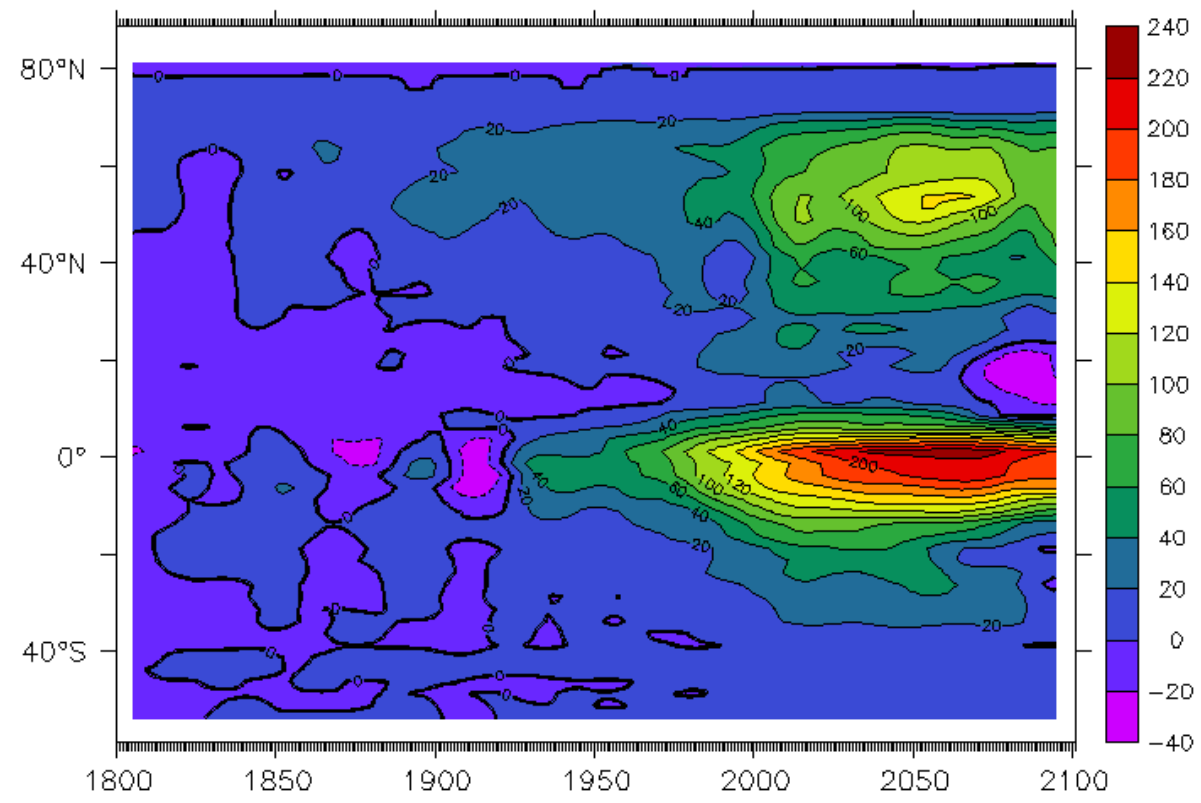

Fig. 8. Net ecosystem production as a function of latitude and time: Global simulation with $\mathrm{N}$ limitation (MtC/year/degree latitude).

\section{Simple parameterization of nitrogen limitation}

G. Krinner et al.

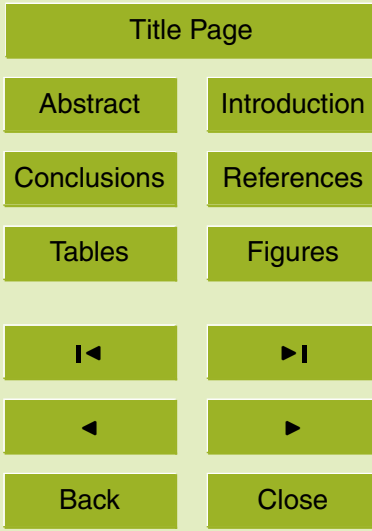

Full Screen / Esc

Print Version

Interactive Discussion 


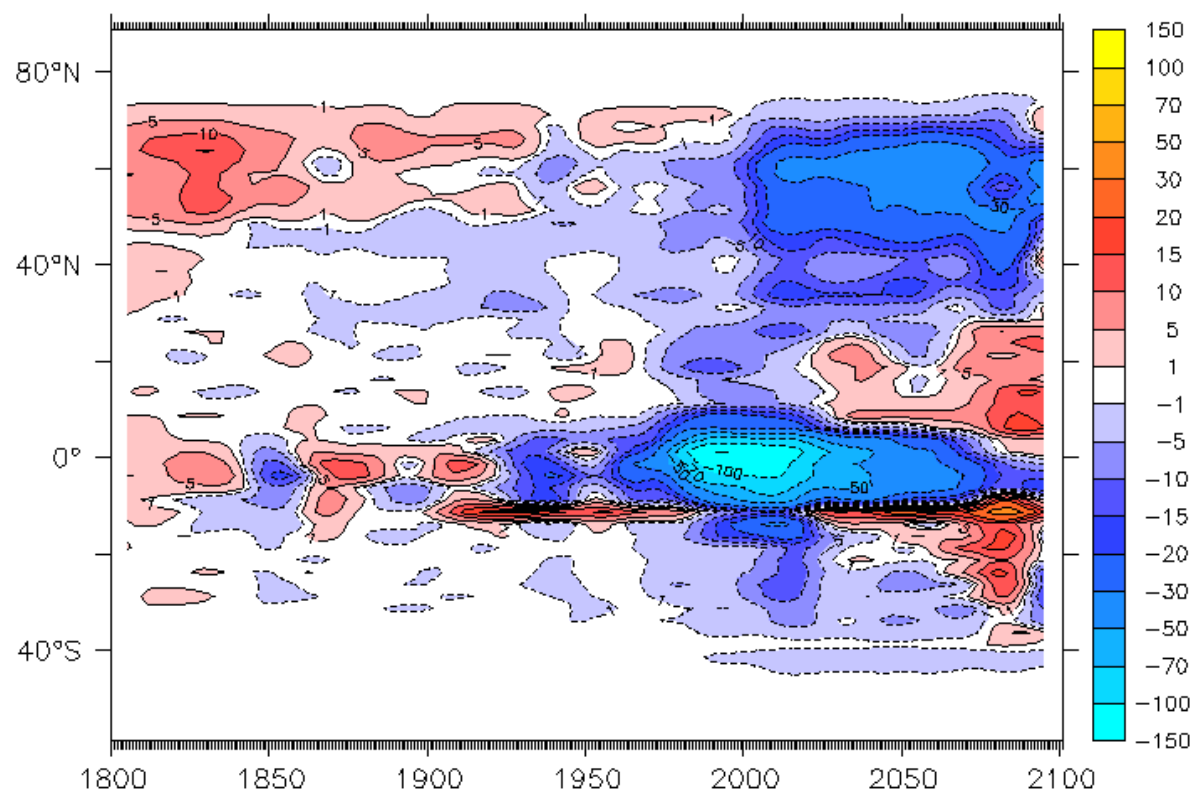

Fig. 9. Net ecosystem production as a function of latitude and time: Global simulation with $\mathrm{N}$ limitation minus global simulation without $\mathrm{N}$ limitation (MtC/year/degree latitude).

\section{Simple parameterization of nitrogen limitation}

G. Krinner et al.

\section{Title Page}

\begin{tabular}{|c|c|}
\hline Abstract & Introduction \\
\hline Conclusions & References \\
\hline Tables & Figures \\
\hline I4 & \\
\hline & \\
\hline Back & Close \\
\hline
\end{tabular}

\section{Full Screen / Esc}

Print Version

Interactive Discussion

\section{EGU}




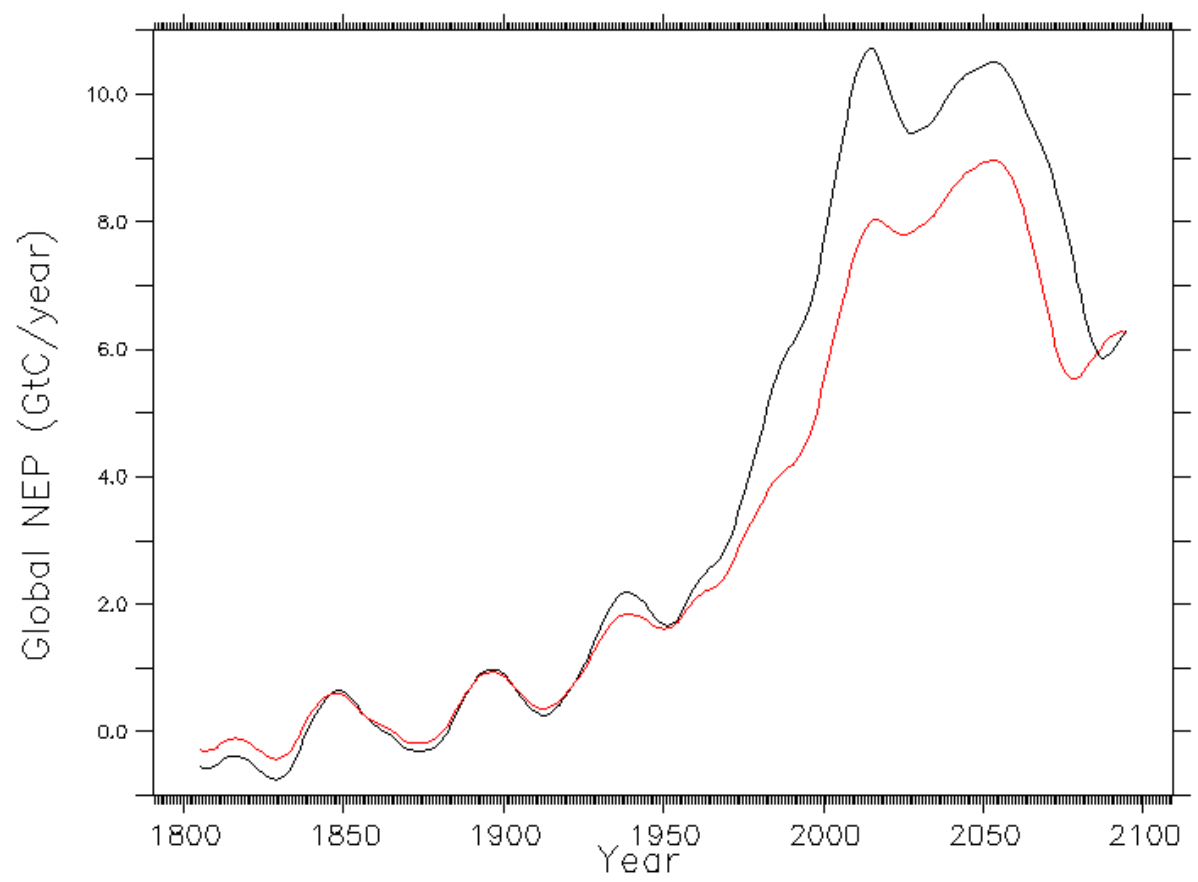

Fig. 10. Global mean net ecosystem production as a function of time: Global simulation with $N$ limitation (red) and global simulation without $\mathrm{N}$ limitation (black) in GtC/year.

\section{Simple parameterization of nitrogen limitation}

G. Krinner et al.

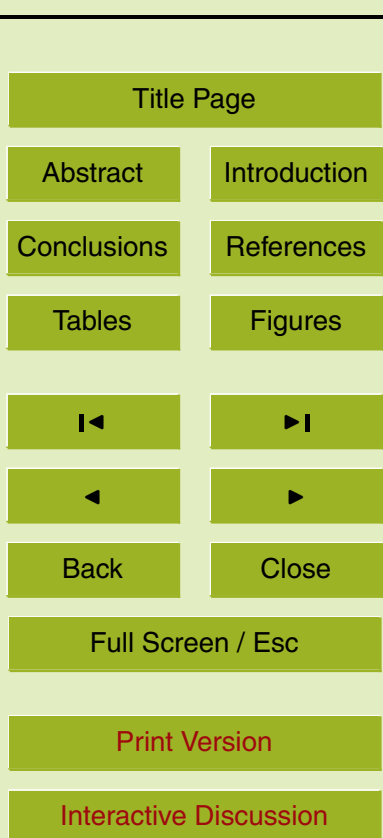

EGU 